\title{
APROVEITAMENTO DO RESÍDUO DO BENEFICIAMENTO DA TILÁPIA DO NILO (Oreochromis niloticus) PARA OBTENÇÃO DE SILAGEM E ÓLEO COMO SUBPRODUTOS
}

\section{LIA FERRAZ DE ARRUDA}

Dissertação apresentada à Escola Superior de Agricultura "Luiz de Queiroz", Universidade de São Paulo, para obtenção do título de Mestre em Ciências, Área de Concentração: Ciência e Tecnologia de Alimentos.

P I R A C I C A B A

Estado de São Paulo - Brasil

Julho - 2004 


\title{
APROVEITAMENTO DO RESÍDUO DO BENEFICIAMENTO DA TILÁPIA DO NILO (Oreochromis niloticus) PARA OBTENÇÃO DE SILAGEM E ÓLEO COMO SUBPRODUTOS
}

\section{LIA FERRAZ DE ARRUDA}

Engenheiro Agrônomo

Orientador: Prof ${ }^{\mathrm{a}}$. Dr ${ }^{\mathrm{a}}$. MARÍLIA OETTERER

\begin{abstract}
Dissertação apresentada à Escola Superior de Agricultura "Luiz de Queiroz", Universidade de São Paulo, para obtenção do título de Mestre em Ciências, Área de Concentração: Ciência e Tecnologia de Alimentos.
\end{abstract}

P I R A C I C A B A

Estado de São Paulo - Brasil

Julho - 2004 


\section{Dados Internacionais de Catalogação na Publicação (CIP) DIVISÃO DE BIBLIOTECA E DOCUMENTAÇÃO - ESALQ/USP}

\section{Arruda, Lia Ferraz de}

Aproveitamento do resíduo do beneficiamento da tilápia do Nilo (Oreochromis niloticus) para obtenção de silagem e óleo como subprodutos.

$78 \mathrm{p}$.

Dissertação (mestrado) - - Escola Superior de Agricultura Luiz de Queiroz, 2004. Bibliografia.

1. Óleo de peixe 2. Resíduo animal 3. Silagem 4. Subproduto animal 5. Tilápia-doNilo I. Título

CDD 664.94 
À $\operatorname{Dr}^{\mathrm{a}}$ Marília Oetterer, responsável pela minha formação acadêmica.

Aos engenheiros agrônomos da família... Principalmente, meu avô, Linneu (in memorian), meu pai, André e para a minha prima Marney

À minha mãe, Cristina, minha avó Lélia (in memorian) e meu marido Willey 


\section{AGRADECIMENTOS}

Á Deus, por sempre estar ao meu lado me protegendo e orientando;

À gloriosa Escola Superior de Agricultura "Luiz de Queiroz" responsável pela minha graduação e pós graduação;

À minha família, principalmente para a minha irmã, Andréa, à Maria de Fátima, à D. Júnia e à minha madrinha, Rosana;

À todos os docentes e funcionários do Departamento de Agroindústria, Alimentos e Nutrição, especialmente para as professoras $\operatorname{Dr}^{\mathrm{a}}$ Marília Oetterer e $\operatorname{Dr}^{\mathrm{a}}$ Marisa Aparecida Bismara Regitano d'Arce, exemplos de carreiras acadêmicas.

À Prof ${ }^{a} \operatorname{Dr}^{\mathrm{a}}$ Marília Oetterer, pela orientação e amizade;

À Prof ${ }^{a}$ Dr $^{\mathrm{a}}$ Marisa Aparecida Bismara Regitano d'Arce pela imprescindível orientação e amizade, e por permitir a utilização do Laboratório de Óleos e Gorduras para a realização do experimento;

Ao professor Dr. José Eurico Possebon Cyrino pela amizade e sugestões durante a realização do trabalho;

Às professoras $\mathrm{Dr}^{\mathrm{a}}$. Marney Pascoli Cereda, $\mathrm{Dr}^{\mathrm{a}}$. Elisabete Maria Macedo Viegas e Dra . Adriana Maria Nolasco pelas sugestões e auxílio nas correções;

Aos amigos Aelson Aloir Santana Brum, Ricardo Borghesi, Roberta Rizzo Benatto e Leandro Portz pela amizade e apoio nos momentos de dificuldade;

À todos do Laboratório de Óleos e Gorduras, Maria Fernanda, Lilian, Roberta e Tatiane pela amizade e auxílio nas análises;

A todos do Laboratório de Pescado pela amizade e, principalmente, para a Ivani Moreno que sempre me orientou durante as análises químicas; 
À Márcia Regina Severino Bertarelli, pela amizade e pela disposição em ajudar sempre que necessário;

Á secretária da pós-graduação, Regina Lúcia Mello Lourenço, pela ajuda na condução dos procedimentos burocráticos do mestrado;

À CAPES, pela bolsa concedida;

A Fundação de Amparo à Pesquisa do Estado de São Paulo, pelo Auxílio Pesquisa que tornou possível a realização desta pesquisa. 


\section{SUMÁRIO}

Página

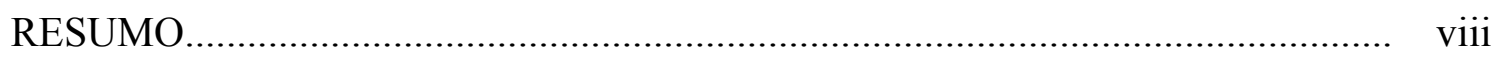

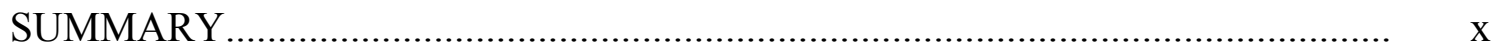

1 INTRODUÇÃ

2 REVISÃO DE LITERATURA............................................................... 5

2.1.Produção, industrialização e aproveitamento do resíduo de pescado.................. 5

2.2 Gerenciamento de resíduos industriais sólidos............................................... 8

2.3 Obtenção da silagem de pescado................................................................... 11

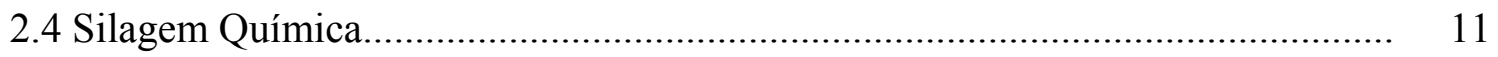

2.5 A utilização de silagem de pescado em rações animais..................................... 13

2.6 Alimentação de Peixes...................................................................................... 15

3 SILAGEM QUÍMICA DE TILÁPIA DO NILO (Oreochromis niloticus) CARACTERIZAÇÃO FÍSICO-QUÍMICA E NUTRICIONAL .............................. 18

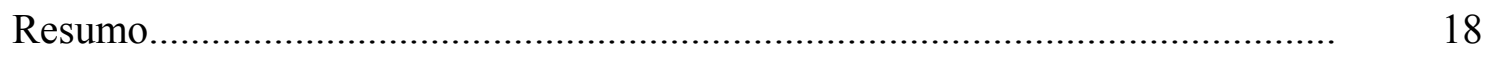

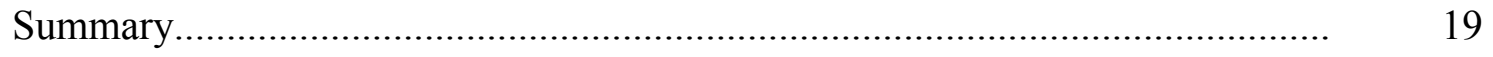

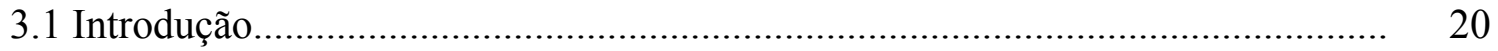

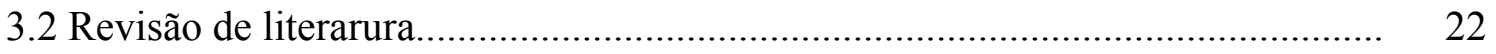

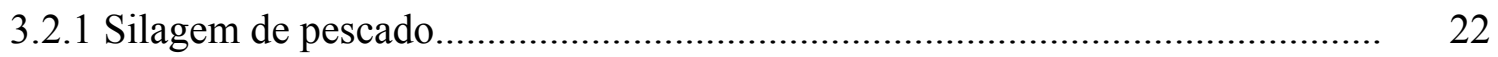

3.2.2 Valor nutricional da silagem............................................................. 23

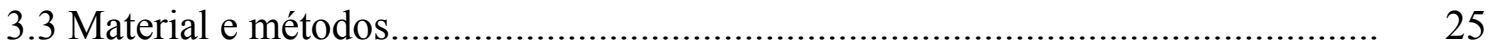

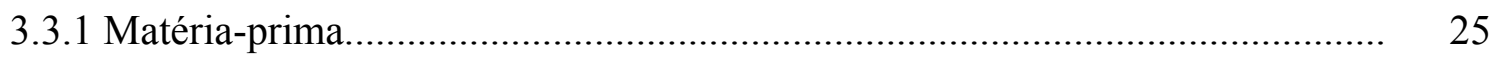

3.3.2 Metodologia de elaboração da silagem..................................................... 25

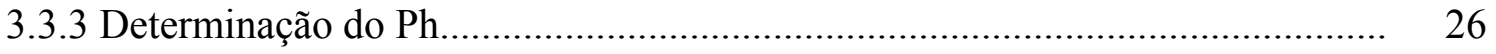


3.3.4 Análise sensorial de acompanhamento...................................................... 26

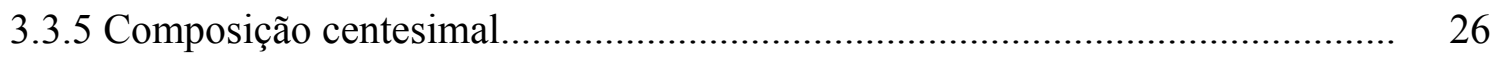

3.3.6 Determinação da composição de aminoácidos............................................... 27

3.3.7 Determinação do escore químico de aminácidos essenciais............................. 27

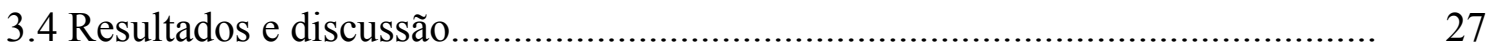

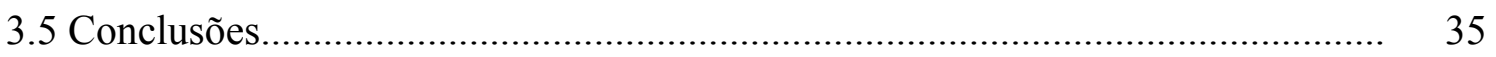

4 RENDIMENTO E QUALIDADE FÍSICO-QUÍMICA DO ÓLEO DE SILAGEM DE TILÁPIA DO NILO (Oreochromis niloticus) OBTIDO PELOS MÉTODOS DE CENTRIFUGAÇÃO, SOXHLET E BLIGH \& DYER................. 36

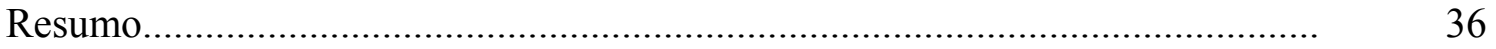

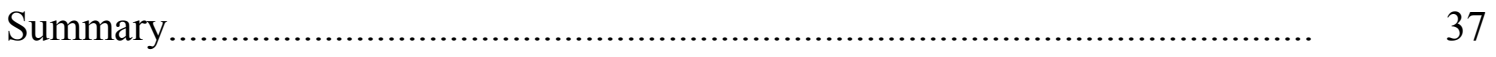

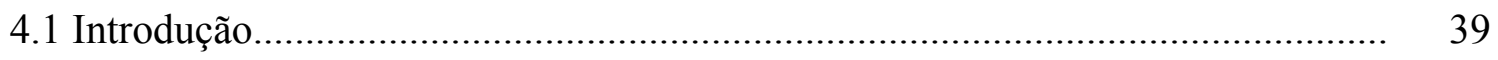

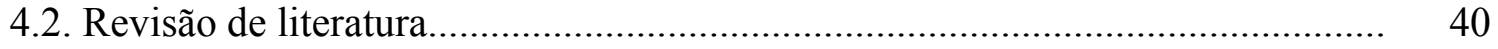

4.2.1 Fração lipídica presente na silagem............................................................. 40

4.2.2. Utilização da fração lipídica de pescado...................................................... 42

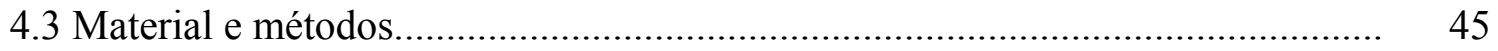

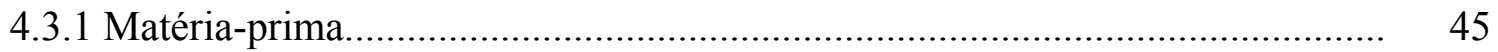

4.3.2 Metodologia de elaboração da silagem....................................................... 45

4.3.3 Obtenção do óleo de pescado................................................................... 46

4.3.4 Análise de Rendimento em óleo................................................................. 47

4.3.5 Preparação das amostras de óleo para análise.............................................. 47

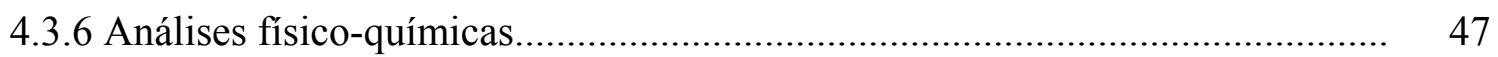

4.3.7 Índice de Peróxido.................................................................................... 48

4.3.8 Composição e caracterização do óleo bruto obtido através da centrifugacão.... 48

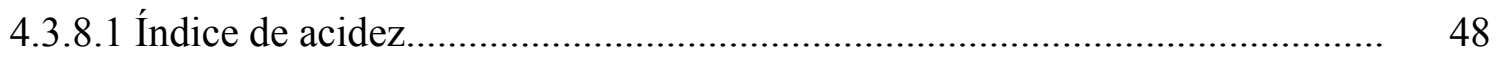

4.3.8.2 Preparo dos ésteres metílicos para cromatografia gasosa............................ 48

4.3.8.3 Composição de ácidos graxos presentes no óleo bruto................................ 49

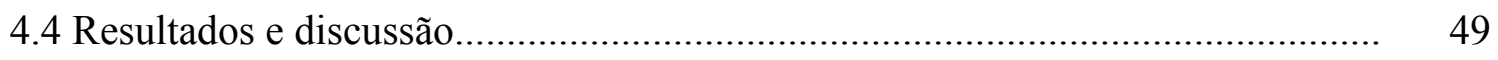

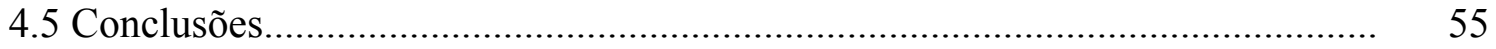

5 CONCLUSÕES GERAIS........................................................................... 57 
REFERÊNCIAS BIBLIOGRÁFICAS................................................................... 59 


\title{
APROVEITAMENTO DO RESÍDUO DO BENEFICIAMENTO DA TILÁPIA DO NILO (Oreochromis niloticus) PARA OBTENÇÃO DE SILAGEM E ÓLEO COMO SUBPRODUTOS
}

\author{
Autora: LIA FERRAZ DE ARRUDA \\ Orientadora: Prof ${ }^{\mathrm{a}}$. Dra ${ }^{\mathrm{a}}$. MARÍLIA OETTERER
}

\section{RESUMO}

Um terço da captura mundial de pescado não é empregada para o consumo direto na alimentação humana, seguindo para elaboração de rações ou é desperdiçada como resíduo. O ideal seria utilizar a matéria-prima em toda a sua extensão e recuperar os subprodutos, evitando a própria formação do resíduo. Com os objetivos de aumentar a receita e a eficiência de produção da indústria e, conseqüentemente, minimizar os problemas ambientais e de sanidade, provenientes do resíduo de pescado, procedeu-se à elaboração da silagem química do resíduo de beneficiamento da tilápia. A tilápia do Nilo (Oreochromis niloticus) é hoje a espécie mais popular no Brasil. A tilápia é cultivada em 22 estados brasileiros e a sua produção anual está entre 30 e 40 mil t. A tilápia foi uma das primeiras espécies oriundas da aqüicultura a ser beneficiada, sendo atualmente comercializada na forma de filés congelados, tecnologia emergente, porém com rendimento de cerca de 30\%. Com isso, há necessidade de se transformar o resíduo gerado com o beneficiamento do filé em subprodutos, diminuindo o impacto ambiental. A silagem foi elaborada após homogeneização em cutter e acidificação da biomassa com 3\% de ácido fórmico: propiônico, 1:1, adição do antioxidante BHT e manutenção do $\mathrm{pH}$ ao redor de 4,0. Foram realizadas análises para determinação da umidade, 
proteína, lipídios e cinza. Os aminoácidos foram examinados em auto analisador após hidrólise ácida, à exceção do triptofano determinado por colorimetria. A silagem de tilápias apresentou teores semelhantes ou maiores aos preconizados pelo padrão da FAO para todos os aminoácidos essenciais, com exceção do triptofano. Os valores mais elevados encontrados foram para o ácido glutâmico, leucina e lisina. Os resultados indicam uma possível utilização da silagem, preparada a partir do resíduo de processamento da Tilápia-do-Nilo, como fonte proteíca na formulação de ração para peixes. Entretanto, para o aproveitamento da silagem é necessário que se estabeleçam técnicas para remoção do óleo presente com a finalidade de aumentar a estabilidade do produto e seu valor comercial. A oxidação dos lipídios presentes pode causar a formação de peróxidos que podem complexar as proteínas com conseqüente destruição dos aminoácidos. O presente trabalho buscou, também, estabelecer a melhor via de extração do óleo presente na silagem ácida de tilápia do Nilo (Oreochromis niloticus), bem como caracterizar o óleo obtido. A fração lipídica foi extraída por três métodos de extração, a saber, centrifugação (3500 × G/30 min), Soxhlet (AOAC,1990) e Bligh \& Dyer (1969). Os resultados para rendimento e índice de peróxido foram, respectivamente, $65,53 \%$ e $0,00 \mathrm{mEq} / 1000 \mathrm{~g}$ de $\mathrm{O}_{2}, 44,27 \%$ e $25,00 \mathrm{mEq} / 1000 \mathrm{~g}$ de $\mathrm{O}_{2}, 46,87 \%$ e $0,00 \mathrm{mEq} / 1000 \mathrm{~g}$ de $\mathrm{O}_{2}$. O óleo de tilápia contém, em mg/100g, 28,60; 16,30 e 3,10 dos ácidos oléico, linoléico e linolênico, respectivamente. A centrifugação demonstrou ser a melhor metodologia de extração, por preservar as características físico-químicas do óleo e propiciar maior rendimento. O conteúdo de lipídios na silagem de tilápias, com base na matéria úmida é de 3,99 $\mathrm{g} / 100 \mathrm{~g}$, com a retirada da fração lipídica através da centrifugação, restou na amostra apenas $1,54 \mathrm{~g} / 100 \mathrm{~g}$ de lipídios, o que é considerado um nível aceitável para inclusão em rações para animais. 


\title{
UTILIZATION OF FISH WASTE FROM THE PROCESSING OF NILE TILAPIA (Oreochromis niloticus) TO OBTAIN FISH SILAGE AND FISH OIL AS BY-PRODUCTS
}

\section{SUMMARY}

\author{
Author: LIA FERRAZ DE ARRUDA \\ Adviser: Prof ${ }^{\mathrm{a}}$. Dra ${ }^{\mathrm{a}}$. MARÍLIA OETTERER
}

One third of the world fishing produce is not directly applied in human consumption. Instead, it is used in the elaboration of feed or wasted as residue. It would be ideal to use the raw material thoroughly and to recover by-products, preventing the generation of residues. With the objectives of increasing the income and the production of the industry, as well as minimizing environmental and health problems from fish residues, chemical silage from Tilapia processing residues was produced. The Nile tilapia (Oreochromis niloticus) is the most popular species in Brazil today. Tilapia is cultivated in 22 Brazilian states and its annual production is between 30 and 40 thousand tons. Tilapia was one of the first aquaculture species to be processed after harvesting, being currently commercialized in the form of frozen fillets, however, with a yield of about $30 \%$. Thus, there is a need for transforming the residues generated by the fillet processing into by-products, minimizing the environmental impact. The silage was elaborated after cutter-homogenization and acidification of the biomass with $3 \%$ formic acid: propionic, 1:1, addition of antioxidant BHT and maintenance of $\mathrm{pH}$ at about 4.0. Analyses for the determination of the moisture, protein, lipids and ash were carried out. The amino acids were examined in an auto analyzer after acid hydrolysis, except for the 
triptophane which was determined through colorimetry. The tilapia silage presented contents that were similar to or higher than the FAO standards for all essential amino acids, except for the triptophane. The highest values found were for lysine and leucine. The results indicate a possible use of the silage prepared from the Nile tilapia processing residue as a proteic source in the manufacturing of fish feed. However For the use of the silage, oil-removing techniques are necessary in order to increase the stability of the product as well as its commercial value. Lipid oxidation may cause peroxide formation, which can produce complex proteins with a consequent destruction of amino acids. The present work tried to determine the best form of extracting the oil from the acid silage of Nile tilapia (Oreochromis niloticus) and to caracterize the silage oil. The lipid fraction was extracted by three extraction methods: centrifugation $\left(3500 \times \mathrm{G} \cdot 30 \mathrm{~min}^{-1}\right)$, Soxhlet (AOAC, 1990) and Bligh \& Dyer (1969). The results for yield and peroxide value were, respectively, $65.53 \%$ and $0.00 \mathrm{mEq} \cdot 1000 \mathrm{~g}^{-1}$ of $\mathrm{O}_{2}, 44.27 \%$ and $25.00 \mathrm{mEq} \cdot 1000 \mathrm{~g}^{-1}$ of $\mathrm{O}_{2}, 46.87 \%$ and $0.00 \mathrm{mEq} \cdot 1000 \mathrm{~g}^{-1}$ of $\mathrm{O}_{2}$. The lipid fraction showed 28,$60 ; 16,30$ and $3,10 \mathrm{mg} \cdot 1000 \mathrm{~g}^{-1}$ of oleic, linoleic and linolenic acids, respectively. Centrifugation proved to be the best extraction methodology due to the preservation of the physicalchemical characteristics of the oil and greater yield. The lipid content of the tilapia silage, on a fresh matter basis, was $3.99 \mathrm{~g} \cdot 100 \mathrm{~g}^{-1}$. With the removal of the lipid fraction by centrifugation, only $1.54 \mathrm{~g} \cdot 100 \mathrm{~g}^{-1}$ of lipids could be found in the sample, which is considered an acceptable level for its inclusion in animal feed. 


\section{INTRODUÇÃO}

A utilização do resíduo do processamento de pescado para obtenção de novos produtos deve ser realizada para efetivação da empresa limpa, com aumento da receita e contribuindo para a preservação ambiental. A maior justificativa, porém é de ordem nutricional, pois o resíduo de pescado constitui cerca de metade do volume da matériaprima da indústria e é uma fonte de nutrientes de baixo custo (Oetterer et al., 2003).

É de suma importância o desenvolvimento de novas tecnologias com vistas à utilização desses peixes, preferencialmente em alimentação humana. Há registro de pesquisas conduzidas com esse objetivo, mas, enquanto o fato não se efetiva, o caminho mais curto seria reverter essas perdas, transformando os resíduos em alimentação animal (Disney \& Hoffman, 1978).

$\mathrm{Na}$ Central de Abastecimento do Governo do Estado de São Paulo - CEAGESP existe grande produção de resíduo de pescado, alcançando, em média, uma tonelada por dia e gerando poluição ambiental, pois esses resíduos são depositados sem nenhum tratamento nos "lixões" urbanos da capital do estado (Vidotti, 2001).

Os resíduos de pescado, junto aos postos de beneficiamento e comercialização, causam sérios problemas de poluição ambiental, pois nem sempre é economicamente viável o transporte dos mesmos para as fábricas de processamento de subprodutos (Nunes, 1999).

A necessidade de se montar sistemas de aproveitamento dos resíduos nas indústrias é de ordem econômica e preservacionista, em termos de conservação de energia. Pode-se pensar desde um maior uso da matéria-prima até o produto final ou ainda, no desenvolvimento de novos produtos mediante a utilização de resíduos (Maia, 1998). 
Segundo Greenshields (1992), a idéia de reciclar resíduos, particularmente de alimentos, não é nova, a exemplo da recuperação do vinho como vinagre, no entanto, a preocupação com a eficiência na utilização da proteína de descarte é atual. No passado, os resíduos se destinavam apenas à fabricação de rações ou eram totalmente descartados.

Os conceitos e razões que direcionam as idéias para utilização dos resíduos são vários, muitas vezes têm vida curta, e freqüentemente são tidos como desperdício de investimento. Não raro, os aspectos científicos e tecnológicos são preteridos por razões de ordem econômica e política. O ideal seria utilizar a matéria-prima em toda sua extensão, e recuperar os subprodutos, evitando a própria formação do resíduo (Maia, 1998).

A indústria do pescado representa um vasto potencial, pois seus descartes podem ser facilmente transformados em produtos com aproveitamento mercadológico, como a farinha. Os resíduos oriundos da produção brasileira de pescado enlatado, cerca de 50\% do peso do peixe inteiro, poderão ser transformados em farinha para consumo animal e em óleo para produção de tintas, vernizes e acabamento de couros (BRASIL, 1985).

Grande parte da tecnologia conhecida para a utilização dos resíduos das indústrias de pescado não se mostra economicamente atrativa, em vista do elevado investimento inicial. Os aterros sanitários e lagoas de tratamento de efluentes não são alternativas recomendáveis, devido ao odor desagradável que provocam nas áreas costeiras ou de águas interiores, quase sempre exploradas como polos de lazer (Lustosa Neto, 1994).

Todo esforço deve ser feito para aumentar o consumo humano de pescado, mas sempre haverá quantidade de peixes que são tidos como inadequados ou que estão em excesso à capacidade de processamento.

De acordo com Oetterer (1999), o material residual de qualquer indústria deve seguir os caminhos já estabelecidos pela legislação. O tratamento do efluente por meio de tanques de decantação ou mesmo lagoas para sedimentação, é feito, normalmente, afim de poder ser distribuído na rede pública de coleta de esgoto.

No caso do pescado, além de haver matéria orgânica aproveitável, particularmente cabeças, coluna vertebral e partes de carne aderidas à coluna, sobras da 
filetagem, o volume é grande, de $50 \%$ ou mais do total do pescado que é beneficiado e processado; é portanto, altamente justificável o aproveitamento deste descarte.

Uma forma de minimizar os problemas ambientais gerados pela grande quantidade de resíduo de pescado é sua transformação em um produto para ser incorporado como ingrediente em rações animais (Ristic et al., 2002). Uma alternativa viável seria destinar o resíduo para a fabricação da silagem de pescado, por ser um produto de fácil elaboração e que não exige alto investimento. $\mathrm{O}$ produto possui boa qualidade nutritiva podendo, portanto, ser de grande utilidade para a alimentação animal (Berenz, 1994).

A farinha de peixe é a fonte protéica de origem animal mais abundante para a manufatura de ração para animais domésticos, 86\% da produção mundial, em 1990, destinaram-se à produção de rações para aves, suínos e ruminantes; o restante para suplementação de rações para animais aquáticos. Um substituto para a farinha, adequado quanto aos aspectos nutricionais e de custo, vem sendo esperado mediante a escassez desse insumo no mercado mundial. (Nogueira Junior et al, 1997).

A silagem de pescado é definida como produto líquido produzido a partir do pescado inteiro ou partes dele, ao qual tenham sido adicionados ácidos, enzimas ou bactérias produtoras de ácido láctico e a liquefação da massa tenha ocorrido pela ação de enzimas já presentes no pescado (Tatterson, 1974).

A silagem pode ser utilizada após uma semana e até um mês de estocada, apresentando composição semelhante à da matéria-prima, alta digestibilidade com presença integral dos aminoácidos constituintes do pescado e, portanto, ser destinada ao uso como ração. A estocagem, se mais longa, constituiria em um ponto crítico nutricional, pois os aminoácidos e os lipídios passam a sofrer alterações.

O aproveitamento deve ser imediato, assim que é escoado das mesas processadoras. Após a evisceração, se manual, o funcionário separa as partes sólidas e as dirige às saídas acopladas aos "twins". No caso de planta automatizada, à saída da máquina filetadora, devem ser acoplados os "twins" que recebem as partes sólidas. Os resíduos das indústrias processadoras de pescado representam sérios problemas de 
sanidade das instalações e interferem nos custos e na eficiência da produção (Oetterer, 2002).

A biomassa homogeneizada deve ser distribuída em tanques, unidades de volume conhecido, que receberão os ácidos propiônico e fórmico para promover autólise e abaixamento de $\mathrm{pH}$ da biomassa. Não deve haver acúmulo deste material, pois se constituiria em um ponto crítico, com facilidade para a ação microbiana; o efeito do ácido permite a conservação da biomassa (Oetterer, 2002).

Os tanques podem ser mantidos ao ambiente e devem ser revolvidos ao final de cada jornada de trabalho para facilitar a ação das enzimas normalmente presentes na carne do pescado, e levar à digestão das proteínas, com conseqüente formação da biomassa pastosa. $\mathrm{O}$ controle do $\mathrm{pH}$ deve ser feito, diariamente, e mantido próximo de 4. Este controle se não efetuado pode se constituir em outro ponto crítico, levando à deterioração da biomassa (Oetterer, 2002). 


\section{REVISÃO DE LITERATURA}

\subsection{Produção, industrialização e aproveitamento do resíduo de pescado}

A produção pesqueira mundial para o ano de 2000 foi de 130,4 milhões de toneladas de pescado. Sendo que 94,8 milhões de toneladas são provenientes da captura e 35,6 milhões correspondem a produção aqüícola mundial (FAO, 2004).

No ano de 1997, segundo a FAO (1998), foram produzidos 122 milhões de toneladas métricas de pescado no mundo. Esse total correspondeu a US\$ 49 bilhões em receitas geradas. A produção brasileira de pescado foi de 798.719 toneladas métricas. Desse total 115.398 toneladas corresponderam a produção aqüícola nacional, o que conseqüente receita de US\$198.000.200,00 (Ostrensky et al., 2000).

De acordo com a FAO (2000), a produção mundial de organismos aquáticos oriundos da aquicultura passou de 28,82, no ano de 1997, para 30,86 milhões de toneladas métricas no ano de 1998. Nesse mesmo período, houve uma redução de mais de 7 milhões de toneladas métricas na produção de organismos aquáticos capturados.

No período de 1996 a 2000, a aqüicultura cresceu de 25,7 para 35,6 milhões de toneladas métricas. Estima-se que em 2001, a produção aqüícola seja de 37,5 milhões de toneladas métricas (FAO, 2004).

Do total da captura mundial de pescado, cerca de $60 \%$ são utilizados nos mercados de peixe fresco, ou processados na forma de congelados, enlatados ou curados, gerando considerável volume de material não aproveitado. Calcula-se que o volume de resíduos gerados pelas plantas processadoras atinja em média, aproximadamente $50 \%$ do total processado. Soma-se a esse total, uma quantia considerável da pesca que não é aproveitada para consumo humano, devido ao seu baixo valor comercial, como também 
pelo descarte daqueles recusados pela Inspeção Federal/Estadual nos Entrepostos de comercialização “in natura” (Laubier, 1979; Hood \& Zall, 1979; Rebeca et al., 1991).

Podemos relacionar que cerca de $50 \%$ da produção pesqueira mundial, que em 2000 foi de 130,4 milhões de toneladas métricas de pescado, tranformou-se em resíduo, ou seja, o expressivo montante de 65, 2 milhões de toneladas métricas de resíduo de pescado.

A sobrepesca comercial ou artesanal vem causando um declínio constante nas populações de peixes das águas interiores do Brasil. Este fato, aliado ao temor de que os peixes capturados na natureza possam estar contaminados com mercúrio das minerações de ouro, tem estimulado o desenvolvimento da piscicultura (Castagnolli, 1995).

A única opção segura para a produção do pescado está na aqüicultura, que avança como uma das atividades agropecuárias de mais rápido crescimento no mundo. Estima-se que, em 2010, ela deverá suprir 25\% da colheita aquática mundial. Em 1993, esta atividade atingiu 17 milhões de toneladas métricas, quando foi feita a estimativa de 20 milhões para o ano 2000. Em 1997, calculava-se que a piscicultura de água doce produzia 8 milhões de toneladas métricas ao ano, ultrapassando a captura, que atingia 5 milhões de toneladas métricas (Nogueira Junior et al., 1997).

De acordo com Ostrensky et al. (2000), a produção aqüícola brasileira passou de 23.390 toneladas métricas em 1991, para 115.398 toneladas métricas, em 1998, um aumento de $393 \%$, crescendo em média cerca de $26 \%$ ao ano, passando da $35^{\mathrm{a}}$ posição, em 1991, para a 26 posição, em 1997, conforme o ranking estabelecido pela FAO.

Mais de $80 \%$ do território brasileiro está localizado na região tropical drenada por duas grandes bacias hidrográficas, a bacia Amazônica e a do Paraná-Paraguai. Nesta última, que cobre o Brasil central, e na bacia do rio São Francisco, que drena as regiões sudeste e nordeste do país, existem mais de 100 grandes reservatórios e barragens, para fins de geração de energia e armazenamento de água, compreendendo mais de 5 milhões de hectares de área alagada. O potencial de exploração deste sistema para piscicultura semi-intensiva ou intensiva é muito grande (Castagnolli, 1995). 
A Amazônia compreende mais de $40 \%$ do território nacional, e é quase totalmente coberta por florestas tropicais, drenadas para o Oceano Atlântico através da bacia do Rio Amazonas, a qual contribui com, aproximadamente, 25\% de aporte de água doce do mundo para o sistema marinho. A despeito das capturas nominais da pesca profissional alcançarem mais de 300 toneladas/ano, o número de piscicultores na região vem aumentando. Em adição, com apoio técnico da Universidade do Amazonas, do Instituto Nacional de Pesquisas da Amazônia - INPA, e do Centro de Pesquisas Agropecuárias do Trópico Úmido - CPATU, muitos produtores comerciais de alevinos se instalaram na região (Castagnolli, 1995).

A região Central compreende a região das planícies pantaneiras, por onde correm os vários tributários do rio Paraguai. O Pantanal é uma região que se estende pelo Brasil Central, partes da Bolívia, Paraguai e Argentina. A região também é considerada um dos últimos santuários da vida selvagem tropical, compreendendo uma área de 1,4 milhões de $\mathrm{km}^{2}$, que permanece alagada a maior parte do ano. O Pantanal é um imenso berçário natural de peixes, que suporta uma pesca de 10 mil toneladas anuais, consumida, principalmente, no Estado de São Paulo (Castagnolli, 1995).

O clima temperado da região Sul, com estações definidas e invernos rigorosos, não favorece a produção de espécies tropicais, que apresentam uma taxa de crescimento muito reduzido ou mortalidade dos estoques naquelas condições. Na parte oeste da região Sul, a piscicultura é praticada por um grande número de médios ou pequenos produtores, tradicionalmente ligados à avicultura ou suinocultura, que reciclando os subprodutos da agroindústria avícola e suinícola, alimentam e produzem um média de $1.500 \mathrm{~kg}$ de peixes/ha/ano, como fonte de renda complementar (Castagnolli, 1995).

Unidades processadoras de filés congelados de peixes de água doce têm se instalado no Brasil, na última década, principalmente nas regiões Sul e Sudeste, aumentando o volume de resíduos não aproveitados (Oetterer, 2002).

As informações colhidas em 2000 sobre as unidades de processamento de pescado instaladas no país deixam a desejar, por exemplo, a Região Sudeste é a que possui o maior número de unidades processadoras (23), mas não há dados suficientes para a quantificação do volume que está sendo processado atualmente. Outro problema, é que, 
como a quantidade de pescado produzido pela aquicultura ainda é pequena, dificilmente uma processadora de porte médio consegue funcionar somente com matéria-prima originada de cultivo. Como ponto positivo ressalta-se que das 47 unidades identificadas, 32 delas (68\% do total) possuem certificado emitido pela inspeção sanitária (Ostrensky et al.,2000).

Intensificar um cultivo implica aumentar a quantidade de biomassa de animais produzidos por área, à custa do fornecimento constante de alimento nutricionalmente adequado. Uma vez que a alimentação dos peixes perfaz de 30 a $70 \%$ do total dos custos operacionais da aqüicultura intensiva, esta, tornou-se o fator unitário mais importante para a administração dos cultivos modernos (Nogueira Junior et al., 1997).

$\mathrm{O}$ desenvolvimento da aquicultura no Brasil tem enfrentado vários problemas relacionados a falta de rações nutricionalmente adequadas e de baixo custo, que possam viabilizar o processo de produção.

Como em qualquer criação animal, a alimentação na aquicultura corresponde a um alto percentual dos custos operacionais, podendo atingir índices que variam de $30 \mathrm{a}$ 60\% do total (El-Sayed, 1999; Cheng et al., 2003). Diversos têm sido os esforços de pesquisadores, em todo o mundo, no sentido de identificar fontes alternativas de proteínas, que permitam uma redução nos custos com alimentação (Fagbenro et al., 1994).

A farinha de peixe deve permanecer como fonte protéica principal de rações para peixes, até surgirem novas opções de menor custo ou de maior facilidade de produção. Atualmente, a farinha é o ingrediente mais crítico nas rações aquáticas, em especial para as espécies carnívoras e para todas as espécies nas fases iniciais, larvas e juvenis (Nogueira Junior et al., 1997).

\subsection{Gerenciamento de resíduos industriais sólidos}

Os aspectos científico e tecnológico são preteridos aos econômicos e políticos que têm mais força. Hoje, com o domínio da biotecnologia espera-se uma reversão de conceitos. Um levantamento feito em 1992, em pesquisa e desenvolvimento na área de 
tecnologia de alimentos na Inglaterra, revelou que as prioridades do segmento da tecnologia de alimentos para a próxima década são, entre outras, novos processos usando enzimas, recuperação de subprodutos e controle da poluição. O ideal será utilizar os subprodutos e assim evitar a própria obtenção do resíduo (Espíndola Filho, 1999).

A bioconversão do material residual com conseqüente aproveitamento deste, trará vantagens econômicas para a indústria, além de sanar o grande problema de eliminação de resíduos, matéria poluente e de difícil descarte.

O termo resíduo refere-se às sobras e aos subprodutos do processamento dos alimentos que são de valor relativamente baixo. A necessidade de se montar sistemas de aproveitamento dos resíduos de indústrias é de ordem econômica e de conservação de energia. Pode-se pensar desde um maior uso da matéria-prima até o produto final, ou ainda, o desenvolvimento de novos produtos que utilizem resíduos líquidos e sólidos no preparo. Para o aproveitamento destes resíduos as ferramentas mais úteis são as enzimas e os microrganismos (Shoemaker, 1986).

Para a United Nations Industrial Development Organization- UNIDO (1991), a recuperação e a utilização de resíduos tanto sólidos quanto líquidos de pescado marinho, pode ser uma medida segura de proteção ao ambiente e à indústria, pois para serem descarregados junto à água, após tratamento, há dificuldades devido ao grande volume, médio a alto DBO (demanda biológica de oxigênio), sólidos em suspensão e altos níveis de gordura e proteína. Assim, a UNIDO realizou um amplo estudo com informações técnicas e custos relativos ao gerenciamento dos resíduos da indústria processadora de pescado. Várias opções são discutidas como, por exemplo, a produção de ração, a silagem ou de "minced". A silagem é sugerida para ser produzida em partidas de $50 \mathrm{~kg}$ ou em tanques de $1 \mathrm{t}$ ou mais, adicionada de carboidratos como o melaço, e para substituir as farinhas de peixe.

Os resíduos da industrialização do pescado podem ser dirigidos para vários tipos de aproveitamento e divididos em 4 categorias: alimentos para consumo humano, ração para animais, fertilizantes ou produtos químicos. A maioria se destina a produção de farinha de peixe utilizada como ingrediente para ração animal. A utilização do resíduo da filetagem caracteriza o aproveitamento na forma de "minced" e pode alcançar o 
maior preço dos produtos reciclados; é útil em países com problemas de desnutrição e origina vários outros produtos como o "surimi” e o "kamaboko". O resíduo sólido, se destinado ao preparo da silagem, necessita como investimento, os recipientes de preparo e estocagem (United, 1991).

A forma mais racional de se utilizar o potencial pesqueiro é recuperando as partes comestíveis dos peixes capturados, como as aparas após desossamento que podem se transformar em "minced fish"; 20 a 30\% da captura acabam sendo descartados, nesta operação. Há busca de novos mercados para novos produtos como os concentrados protéicos e as proteínas texturizadas (Horisberger, 1979).

O aproveitamento das sobras comestíveis das operações tradicionais de filetagem ou de corte em postas de pescado assume importância muito grande, pois além de abaixar os custos dos insumos principais, minimiza os problemas de produção e o custo unitário das matérias-primas, quando comparado aos produtos acabados (Moraes Martins, 1981; Oetterer, 1999).

É de grande relevância a inserção do aproveitamento de resíduos na cadeia produtiva de pescado, com o intuito de evitar desperdícios, reduzir os custos de produção do pescado e a poluição ambiental, pois com a criação de alternativas tecnológicas com valor agregado que permitam o gerenciamento dos resíduos sólidos de pescado, teremos como resultado a segurança alimentar através do combate a fome, geração de empregos e o desenvolvimento sustentado (Espindola Filho, 1997).

No Brasil, o aproveitamento dos resíduos do comércio de pescado é pequeno; na indústria enlatadora aproveita-se as sobras para preparo de farinha de peixe de baixa qualidade. Este resíduo é acumulado em tanques sem receber qualquer tipo de tratamento, fato que depõe contra a qualidade higiênica dessas plantas de processamento. Um manejo adequado do material descartado, com separação das partes comestíveis e estocagem em condições ácidas possibilitaria à indústria brasileira a preparação da silagem, até mesmo para consumo humano (Valério, 1994).

Nos últimos anos tem se enfatizado cada vez mais o estudo das interfaces entre os ecossistemas, com a certeza de que as interações entre os diferentes sistemas, desempenham um papel vital no desenvolvimento e no equilíbrio dos mesmos. A 
poluição hídrica, causada basicamente pela atividade antrópica, pode ser facilmente detectada em muitos rios e lagos do mundo inteiro, bem como nos mares próximos das grandes cidades e tem se tornado tão sério que é hoje uma grande ameaça ao suprimento de água potável em muitas regiões do mundo, porque os leitos subterrâneos acham-se contaminados por substâncias químicas e/ou biológicas. Entre os impactos ambientais mais evidentes, estudados sobre a natureza de projetos na Amazônia, por exemplo, está incluído o de processamento de pescado, caracterizado como um tipo de investimento com efeitos nocivos de seus efluentes, constando a presença de óleos, sólidos em suspensão, alteração do $\mathrm{pH}$, e da DBO, e outros parâmetros a serem considerados, como por exemplo, a introdução errônea de resíduos, diretamente no corpo d'água, sem nenhum tipo de tratamento e/ou aproveitamento (Espindola Filho, 1997).

\subsection{Obtenção da silagem de pescado}

A silagem de pescado é definida como um produto líquido, produzido a partir do pescado inteiro ou partes dele, ao qual tenham sido adicionados ácidos, enzimas ou bactérias produtoras de ácido láctico e a liquefação da massa tenha ocorrido pela ação de enzimas já presentes no pescado (Tatterson, 1974).

Conforme Kompiang (1981), a silagem, a partir do pescado inteiro ou do material residual, pode ser obtida pela ação de ácidos (silagem química) ou por fermentação microbiana induzida por carboidratos (silagem microbiológica). A liquefação é conduzida pela atividade de enzimas proteolíticas, naturalmente presente nos peixes, ou adicionadas com o objetivo de acelerar o processo (silagem enzimática).

\subsection{Silagem Química}

A silagem ácida foi desenvolvida em 1920, por A. I. Virtanen, utilizando ácidos clorídrico e sulfúrico para conservação de forragens. Experimentos com peixes se iniciaram, em 1936, na Suécia, utilizando ácidos clorídrico, sulfúrico, açúcares e ácido fórmico (Tatterson et al., 1974). 
Segundo Kompiang (1981), ácidos orgânicos, como o ácido fórmico, são geralmente mais caros que os minerais, no entanto produzem silagens menos ácidas e que não exigem neutralização antes do uso.

Disney et al. (1977) concluíram, em seus experimentos, que a combinação de um ácido mineral e o ácido fórmico (combinando assim um baixo pH com uma ação bactericida) promoveram um econômico e eficiente tratamento ácido. Várias concentrações do ácido fórmico e níveis de $\mathrm{pH}$ foram testados e os níveis requeridos encontrados dependeram das espécies de peixes e das condições de produção.

A ação bactericida do ácido deve ser considerada. Uma mistura de ácidos fórmico e propiônico tem sido recomendada. No caso de se utilizar a proporção 1:1; fórmico- propiônico e adição de $3 \%$ volume/peso à biomassa, a silagem que se obtém é estável, com aroma acidificado (Kompiang, 1981).

Em trabalho desenvolvido com sardinhas do Mediterrâneo (Sardina pilchardus), citado por Tatterson \& Windsor (1974) indicou-se que a solução mais aceitável e de menor custo para a utilização de ácidos na preservação do material residual era a mistura de 6:1 ácido sulfúrico/ ácido fórmico.

O uso de ácido fórmico, para preservação de material residual destinado a rações, teve inicio após a Segunda Guerra. Na preparação da silagem química, a escolha do reagente de preservação cai entre o ácido inorgânico, a mistura de ácidos, ácidos orgânicos ou a mistura de inorgânicos e orgânicos; estes, como o fórmico, são geralmente mais caros do que os ácidos inorgânicos comuns, mas produzem silagens que não são excessivamente ácidas e, portanto, não necessitam neutralização prévia ao uso. Os ácidos inorgânicos como o ácido hidroclorídrico e o ácido sulfúrico podem ser recomendados, devido ao baixo custo (Oetterer, 1999).

Para o preparo da silagem química, a matéria-prima, preferencialmente, deve se apresentar em pequenos pedaços ou ser moída. A seguir, adiciona-se o ácido para permitir a ação deste, até a liqüefação ocorrer. Normalmente, emprega-se a temperatura ambiente e o tempo decorrente da estocagem desse sistema levará às modificações bioquímicas desejadas. É importante revolver a mistura para que a matéria-prima entre em contato com o ácido, uma vez que as partes do material sem tratamento podem entrar 
em putrefação. Após a mistura inicial, o processo de silagem se inicia naturalmente, mas o revolvimento ocasional proporciona a obtenção da uniformidade desejada (Oetterer, 1999).

A mistura do ácido sulfúrico com ácido fórmico ou com o ácido fosfórico na proporção de 3:1, ambos a 3,5\%, mostrou ser eficiente na produção da silagem química. Esta possibilidade de substituição do ácido fórmico pelo ácido fosfórico é interessante, pois permite a diminuição nos custos de produção desta silagem (Espindola Filho, 1999).

\subsection{A utilização de silagem de pescado em rações animais}

Em países tropicais, grande quantidade de pescado é perdida, especialmente em pesca de pequeno porte. É de suma importância o desenvolvimento de novas tecnologias com vistas à utilização destes peixes, preferencialmente em alimentação humana. Há registro de pesquisas conduzidas com este objetivo, mas, enquanto o fato não se efetiva, o caminho mais curto seria reverter estas perdas, transformando os resíduos em alimentação animal. A silagem de pescado vem a representar uma alternativa bastante atraente para a utilização desses resíduos (Disney \& Hoffman, 1978).

A farinha de peixe é a fonte protéica de origem animal mais abundante para a manufatura de ração para animais domésticos; 86\% da produção mundial, em 1990, destinaram-se à produção de rações para aves, suínos e ruminantes; o restante para suplementação de rações para animais aquáticos. Um substituto para a farinha, adequado quanto aos aspectos nutricionais e de custo, vem sendo esperado mediante a escassez desse insumo no mercado mundial (New, 1995; Nogueira Junior et al., 1997).

No Brasil, a farinha de peixe produzida na Região Sudeste é totalmente consumida na região, que também é um dos maiores parques industriais de criação de aves do país (Mencia Morales et al., 1976).

A farinha de peixe é um dos produtos protéicos de origem animal mais usados nas rações. Sua produção exige grande empate de capital, equipamentos especiais e alto 
consumo energético, com capacidade ociosa em algumas épocas do ano, elevando o preço do produto (Lessi et al., 1989).

As vantagens da produção da silagem em comparação a de farinha de pescado são as seguintes: o processo é virtualmente independente de escala; a tecnologia é simples; o capital necessário é pequeno, mesmo para produção em larga escala; os efluentes e problemas com odor são reduzidos; o processo da ensilagem é rápido em climas tropicais e o produto pode ser utilizado no local, porém as desvantagens estão no fato do produto ser volumoso, se na forma pastosa, a não ser que seja utilizado desidratado como ingrediente de rações, o que implica no custo adicional da secagem. (Kompiang, 1981).

Em escala comercial, a silagem vem sendo produzida na Polônia e na Dinamarca, desde os anos 60, para a produção de alimentos para aves e suínos ou incorporada a rações como complemento protéico, compondo alimentos para animais domésticos e peixes provenientes da aquacultura. Na França, foi produzido um hidrolisado protéico de pescado com $90 \%$ de proteína, desossado e que alcançou US\$1.500.00 por tonelada. $\mathrm{Na}$ Indonésia, a silagem foi produzida em escala experimental e utilizada em rações que substituiram a farinha de peixe e a de soja, na alimentação de suínos, peixes e aves. Apesar de comum nos países escandinavos, onde são utilizadas há muitos anos com sucesso, a produção industrial de silagem é limitada devido ao alto teor de umidade, o que torna difícil o transporte do produto a longas distâncias(Kompiang, 1981).

Para Windsor (1974) há possibilidade de se proceder à secagem da silagem, para produção de concentrado protéico de pescado, pois enquanto a farinha apresenta cerca de $70 \%$ de proteína, a silagem apresenta $16 \%$.

Saber se haverá matéria-prima para sustentar a crescente demanda por rações, foi tema de discussão do "World Aquaculture 97"; uma das constatações foi a de que haveria a dependência, para a alimentação aqüícola, da produção de farinha e de óleo de peixe (Wiefels, 1998).

Embora uma considerável quantidade de silagem líquida seja produzida na Europa, principalmente para a alimentação animal, nenhuma, por enquanto, é produzida nos trópicos. Mencionam-se alguns experimentos que estão sendo conduzidos, mas, 
mais informações são necessárias a respeito de experimentos de países em desenvolvimento.

\subsection{Alimentação de Peixes}

A utilização da silagem de pescado na alimentação de peixes tem sido, nos últimos tempos, amplamente estudada. Muitos autores acreditam que devido a semelhança desta fonte protéica com a matéria-prima, a silagem tenha elevado potencial para a utilização na aquicultura. Outros autores se apoiam na justificativa do baixo custo, principalmente quando comparado ao da farinha de peixe (Disney et al., 1977; Hussain \& Offer, 1987; Fagbenro et al., 1994).

Fagbenro et al. (1994 e 1995) estudando o valor nutricional de dietas contendo silagem microbiana de pescado, parcialmente desidratadas pela adição de farinha de soja, subproduto de aves ou farinha de ossos e carne, constataram que não ocorreram diferenças significativas nos parâmetros de desempenho e de utilização da proteína quando comparadas à dieta composta por farinha de peixe. $\mathrm{O}$ experimento mostrou que estas dietas, principalmente a composta por silagem e farinha de soja, podem ser utilizadas na alimentação de tilápias, Oreochromis niloticus (onívora) e bagre Africano Clarias gariepinus (carnívoro), sem que o desempenho, a utilização da proteína e a composição da carcaça sejam afetados.

$\mathrm{Na}$ criação do salmão, a busca por dietas que promovam o rápido crescimento, favoreçam a sanidade dos peixes, resultem em produtos de qualidade e tenham baixo custo, é indispensável. Alguns autores, buscando avaliar a utilização da silagem de pescado na alimentação do salmão (Salmo salar), concluíram que esta fonte apesar de não promover melhor desempenho também não causa diminuição neste desempenho, no entanto pode ser obtida a um custo muito inferior (Espe et al. 1992; Heras et al. 1994).

Para o abalone (Haliotis fulgens), o alimento natural é uma microalga. Nos Estados Unidos, esta microalga é usada como o principal alimento. Dietas comerciais são produzidas somente no Japão e Nova Zelândia, mas o alto custo as torna inconvenientes. Dessa forma, o desenvolvimento de dietas artificiais é necessário, 
preferencialmente com um baixo custo. Com base nisto, Viana et al. (1994) avaliaram a utilização da silagem como um alimento alternativo. Os autores concluíram que a silagem de peixe é muito atrativa mas não muito palatável, por isto, recomendam o uso da silagem combinada com outro ingrediente mais palatável, como a farinha de milho, por exemplo.

$\mathrm{Na}$ alimentação do pirarucu (Arapaima gigas), um peixe carnívoro de grande importância na região amazônica, Honczaryk \& Maeda (1998) estudaram a utilização de dietas a base de ensilado biológico de pescado, concluindo que os peixes alimentados desta forma apresentaram maior nível de ingestão. E o mais importante é que a tecnologia empregada na elaboração do ensilado biológico, mostrou-se adequada para a obtenção de um produto próprio, para ser utilizado como base protéica na preparação de rações para a alimentação de pirarucu, podendo ser elaborado em nível artesanal, sem equipamentos sofisticados e sem mão de obra especializada.

É interessante lembrar que, em termos nutricionais, a dieta recebida pelos peixes cultivados pode definir o perfil de ácidos graxos da carne do peixe. Assim, por exemplo a dieta do "catfish" (Ictalurus punctatus) suplementada com 2, 4 e 6\% de óleo de "menhaden" (Brevoortia tyranunus) proporcionou 5,7; 8,4 e 10,1\% de ácidos graxos $\omega$ 3, respectivamente, no músculo dos peixes. Ainda, a suplementação de tilápias (Oreochromis niloticus) com óleo de sardinha (Sardinella, sp) resultou em maior proporção dos ácidos eicosapentaenóico e docosahexanóico (Haard, 1992).

O ensilado de peixe pode ser utilizado como alimento para peixes carnívoros e onívoros, fornecendo proteínas de boa qualidade e alta digestibilidade (Lupin, 1983). Em pesquisas realizadas no Instituto Nacional de Pesquisas da Amazônia-INPA, e divulgadas pelos informativos da FAO, Lessi et al. (1989), Ximenes Carneiro (1991) e Ximenes Carneiro et al (1996) testaram pela primeira vez no Brasil, o ensilado biológico de pescado na alimentação de alevinos de tambaqui (Colossoma macroponum) e na alimentação de pós larva de camarão (Macrobrachium rosembergii). Os autores apontam o ensilado como uma alternativa e um substituto potencial da farinha de peixe e da farinha de carne e ossos nas rações destinadas ao tambaqui. Vários tipos de silagens foram preparadas com resíduos de jaquari (Semaprochilodus, ssp) com adição de 
componentes como farinha de pupunha, resíduos de hortaliças e frutas da região, como repolho e mamão; as dietas além do ensilado biológico eram acrescidas de soja, milho e complexo vitamínico-mineral. 


\section{SILAGEM QUÍMICA DE TILÁPIA DO NILO (Oreochromis niloticus) - CARACTERIZAÇÃO FÍSICO-QUÍMICA E NUTRICIONAL $=$ CHEMICAL NILE TILAPIA FISH SILAGE (Oreochromis niloticus) - PHYSICAL- CHEMICAL AND NUTRITIONAL CHARACTERIZATION}

\section{Resumo}

Um terço da captura mundial de pescado não é empregada para o consumo direto na alimentação humana, seguindo para elaboração de rações ou é desperdiçada como resíduo. O ideal seria utilizar a matéria-prima em toda a sua extensão e recuperar os subprodutos, evitando a própria formação do resíduo. Com os objetivos de aumentar a receita e a eficiência de produção da indústria e, consequentemente, minimizar os problemas ambientais e de sanidade, provenientes do resíduo de pescado, procedeu-se à elaboração da silagem química do resíduo de beneficiamento da tilápia. A tilápia do Nilo (Oreochromis niloticus) é hoje a espécie mais popular no Brasil. A tilápia é cultivada em 22 estados brasileiros e a sua produção anual está entre 30 e 40 mil t. A tilápia foi uma das primeiras espécies oriundas da aqüicultura a ser beneficiada, sendo atualmente comercializada na forma de filés congelados, tecnologia emergente, porém com rendimento de cerca de $30 \%$. Com isso, há necessidade de se transformar o resíduo gerado com o beneficiamento do filé em subprodutos, diminuindo o impacto ambiental. A silagem foi elaborada após homogeneização em cutter e acidificação da biomassa com $3 \%$ de ácido fórmico : propiônico, 1:1, adição do antioxidante BHT e manutenção do pH ao redor de 4,0. Foram realizadas análises para determinação da umidade, proteína, lipídios e cinza. Os aminoácidos foram examinados em auto analisador após hidrólise 
ácida, à exceção do triptofano determinado por colorimetria. A silagem de tilápias apresentou teores semelhantes ou maiores aos preconizados pelo padrão da FAO para todos os aminoácidos essenciais, com exceção do triptofano. Os valores mais elevados encontrados foram para o ácido glutâmico, leucina e lisina. Os resultados indicam uma possível utilização da silagem, preparada a partir do resíduo de processamento da Tilápia-do-Nilo, como fonte proteíca na formulação de ração para peixes.

\section{Summary}

One third of the world fishing produce is not directly applied in human consumption. Instead, it is used in the elaboration of feed or wasted as residue. It would be ideal to use the raw material thoroughly and to recover by-products, preventing the generation of residues. With the objectives of increasing the income and the production of the industry, as well as minimizing environmental and health problems from fish residues, chemical silage from Tilapia processing residues was produced. The Nile tilapia (Oreochromis niloticus) is the most popular species in Brazil today. Tilapia is cultivated in 22 Brazilian states and its annual production is between 30 and 40 thousand tons. Tilapia was one of the first aquaculture species to be processed after harvesting, being currently commercialized in the form of frozen fillets, however, with a yield of about $30 \%$. Thus, there is a need for transforming the residues generated by the fillet processing into by-products, minimizing the environmental impact. The silage was elaborated after cutter-homogenization and acidification of the biomass with $3 \%$ formic acid: propionic, 1:1, addition of antioxidant BHT and maintenance of $\mathrm{pH}$ at about 4.0. Analyses for the determination of the moisture, protein, lipids and ash were carried out. The amino acids were examined in an auto analyzer after acid hydrolysis, except for the triptophane which was determined through colorimetry. The tilapia silage presented contents that were similar to or higher than the FAO standards for all essential amino acids, except for the triptophane. The highest values found were for lysine and leucine. The results indicate a possible use of the silage prepared from the Nile tilapia processing residue as a proteic source in the manufacturing of fish feed. 


\subsection{Introdução}

Na última década, a aqüicultura foi a única atividade relacionada com a produção de alimentos que cresceu a um ritmo superior a $10 \%$ ao ano e por isso vem ganhando importância como fonte de proteína animal. E como tal, deverá assumir a responsabilidade pelo suprimento do déficit da demanda de pescado, uma vez que a pesca extrativa tanto de mar quanto de águas interiores situa-se abaixo da metade do potencial, com tendência a estabilização ou queda (Castagnolli, 1997).

O crescimento da aqüicultura, associado ao aumento de práticas de cultivo cada vez mais intensivas, gerou um aumento na demanda por alimentos de alta qualidade (Espe \& Lied, 1999) que permitam formular dietas de alto valor nutricional, economicamente viáveis e ambientalmente corretas.

Como em qualquer criação zootécnica, a prática da alimentação na piscicultura corresponde a um alto percentual dos custos operacionais, podendo atingir índices que variam em torno de 40 a $60 \%$. Os ingredientes protéicos são responsáveis pela maior parte desse custo (El-Sayed, 1999; Cheng et al., 2003).

Devido ao seu alto valor biológico, equilíbrio em aminoácidos e ácidos graxos, altos níveis de cálcio e fósforo e vitaminas lipo e hidrossolúveis, a farinha de peixe é considerada a principal fonte de proteína dietética em rações para peixes e que proporciona o máximo desempenho. (Pezzato, 1995; Sales \& Britz, 2003).

New \& Csavas (1995) discutem que, com o aumento da demanda por alimentos aquáticos, o preço da farinha de peixe poderá se elevar com conseqüente declínio no fornecimento.

Atualmente, as tilápias são uma das espécies de peixe mais produzidas no mundo, com uma produção estimada em 1.265 .780 toneladas métricas, em 2000 (FAO, 2003b).

Introduzida no Brasil em 1971, a tilápia do Nilo (Oreochromis niloticus) apresentou produção de 35000 toneladas em 1998, sendo a espécie de pescado de água doce mais cultivada no Brasil (BRASIL, 2002; Lovshin \& Cyrino, 1998; MainardesPinto et al., 1995). 
A tilápia é considerada uma das espécies mais promissoras para a aqüicultura, devido a sua rusticidade, rápido crescimento e pelo hábito alimentar onívoro, consumindo ração logo após o início da alimentação exógena (Lovshin, 1998; Lovshin \& Cyrino, 1998).

A carne da tilápia possui boas características organolépticas. De acordo com Chambers IV \& Robel (1993), este peixe apresenta a carne sem espinhos intramusculares, de cor branca, textura firme, aspecto suculento e de sabor apreciável. Apresenta um rendimento em filé de, aproximadamente, $33 \%$ e a comercialização é feita quando os espécimens atingem $350 \mathrm{~g}$ e até $1000 \mathrm{~g}$ (Tachibana, 2002). Com o aumento no número de plantas processadoras de tilápias (Oreochromis niloticus), o resíduo dessa atividade se tornou um problema.

$\mathrm{O}$ aproveitamento deste material que seria desperdiçado, rico em proteína e lipídios, é de extrema importância, pois além de diminuir os custos e aumentar a eficiência de produção, também minimiza os problemas de poluição ambiental que seriam gerados pela falta de destino adequado para este material (Dapkevicius et al., 1998, 2000; Espindola Filho, 1997, 1999; Mantra, 2000; Morais \& Martins, 1981; Samuels et al., 1991).

A elaboração de silagem de pescado é simples, não requerendo equipamentos e procedimentos onerosos, como os empregados na produção de farinha de peixe e poderia ser uma solução para o resíduo do processamento da tilápia (Coello et al., 2000; Disney et al., 1977; Jackson et al., 1984a, 1984b; Martin \& Bemister, 1994; Ottati et al., 1990; Raa \& Gilberg, 1982; Tatterson \& Windsor, 1974).

Muitos autores acreditam que devido à semelhança desta fonte protéica com a matéria-prima, a silagem de pescado tenha elevado potencial para a utilização na aquicultura. $\mathrm{O}$ ensilado elaborado com várias espécies de peixes pode ser utilizado na formulação de rações, fornecendo proteínas de boa qualidade e alta digestibilidade (Fagbenro et al., 1994; Fagbenro \& Jauncey, 1995a; Fagbenro \& Bello-Olusoji, 1997; Heras et al. 1994; Hussain \& Offer, 1987; Lessi et al. 1989; Parín \& Zugarramurdi, 1994; Vidotti, 2001). 
Os objetivos desta pesquisa foram tratar o resíduo do beneficiamento da tilápia (Oreochromis niloticus), em coleta diferenciada, para obtenção de silagem química e caracterizá-la quanto à composição em umidade, proteínas, lipídios, cinza e aminoácidos.

\subsection{Revisão de literarura}

\subsubsection{Silagem de pescado}

A ensilagem de resíduos de pescado é uma técnica antiga de preservação da matéria orgânica. A metodologia para preservação do resíduo de pescado foi adaptada por Edin na década de 30, a partir de um método patenteado por Virtanen na década de 20, que utilizava os ácidos sulfúrico e clorídrico para preservação de forragens (Hammoumi et al., 1998; Raa \& Gilberg, 1982).

Desde a década de 40, a silagem tem sido produzida em muitos países, como Canadá, Inglaterra, Noruega e Alemanha, mas foi somente na Dinamarca, Polônia e Noruega que o processamento da silagem prosseguiu em escala comercial (Sales, 1995).

A ensilagem de resíduos de pescado é uma técnica antiga de preservação da matéria orgânica, na qual, a preservação pode ser feita quimicamente, através da acidificação direta utilizando ácidos orgânicos e/ou minerais (Rivero \& Viana, 1996), biologicamente, onde a acidificação é realizada por microrganismos produtores de ácido lático (Hassan \& Heath, 1987; Vizcarra-Magaña et al., 1999; Zahar et al., 2002) ou pela combinação dos dois métodos (Morales-Ulloa \& Oetterer, 1995).

Na preparação da silagem química, a escolha do reagente de preservação se situa entre o ácido mineral, a mistura de ácidos, ácidos orgânicos ou a mistura de inorgânicos e orgânicos; estes, como o ácido fórmico, são geralmente mais onerosos do que os ácidos minerais comuns, porém produzem silagens que não são excessivamente ácidas e que não exigem neutralização antes do uso (Kompiang, 1981). Os ácidos inorgânicos como o ácido hidroclorídrico e o ácido sulfúrico podem ser utilizados, pois são de baixo custo (Espindola Filho, 1999; Oetterer, 1999 ). 
De acordo com vários autores, a silagem produzida com uma mistura de ácidos fórmico e propiônico, na proporção de 1:1 e adição de 1,5 a 3,0\% (v/p) em relação à massa, é recomendada e o produto obtido é estável e livre de microrganismos patógenos (Goddard \& Al-Yahyai, 2001; Kompiang, 1981; Morales-Ulloa, 1994; Morales-Ulloa \& Oetterer, 1995, 1997; Valério, 1994).

\subsubsection{Valor nutricional da silagem}

A farinha de peixe tem sido, durante anos, a fonte protéica de origem animal mais utilizada em dietas balanceadas para peixes, sendo considerada indispensável para a obtenção de um crescimento adequado, devido ao teor e qualidade da sua proteína, além de atuar como palatabilizante (Furuya, 2000; Furuya et al., 2001).

Diversas pesquisas vêm sendo realizadas na busca por um substituto adequado para a farinha de peixe, quanto aos aspectos nutricionais e de custo (Chong et al., 2002; Fontaínha-Fernandes et al., 1999; Guzmán \& Viana, 1998; Portz, 2001a, 2001b; Stone et al., 2000).

De acordo com Morales-Ulloa (1994) e Valério (1994) a silagem de pescado não deve ser vista como um produto competidor com a farinha de peixe, mas sim como mais uma alternativa na utilização das fontes disponíveis.

A silagem possui alto valor nutricional e biológico para a alimentação animal, conservando a qualidade protéica do produto, particularmente de aminoácidos como a lisina, metionina e cistina (Coello et al., 2000; Ristic et al., 2002; Vidotti et al., 2003).

$\mathrm{O}$ valor nutricional da silagem está na digestibilidade protéica desta que deve ser preservada, evitando-se estocagem prolongada; o grau de hidrólise deve ser utilizado como um critério da qualidade, pois se ocorrer autólise e conseqüente rancificação, o produto fica prejudicado. Após 30 dias de estocagem, cerca de 75 a $85 \%$ do teor de nitrogênio se apresenta na forma solubilizada (Tatterson \& Windsor, 1974; Raa \& Njaa, 1989). Em comparação à farinha de pescado, a silagem apresenta teores mais baixos de aminoácidos sulfurados, porém mais elevados de lisina (Backoff, 1976).

Durante o processo de ensilagem, as proteínas são hidrolisadas pela ação das enzimas proteolíticas naturalmente presentes no pescado e/ou adicionadas (silagem 
enzimática), favorecidas pelo controle da acidez que também auxilia na inibição da ação microbiana, originando um produto liqüefeito, rico em proteínas, peptídeos de cadeia curta e aminoácidos livres. O teor de solúveis aumenta de 10 a 20\% nos primeiros dias de estocagem; aos 3 dias, $50 \%$ do nitrogênio está sob a forma não protéica e o teor de aminoácidos livres aumenta, rapidamente, durante os 5 primeiros dias. Após 10 dias, o aumento em solúveis é de 75\% e após um mês, de 85\% (Stone \& Hardy, 1986; FAO, 2003b, Kompiang, 1981).

Durante o armazenamento prolongado, grande número de aminoácidos livres está presente na silagem devido à atividade das enzimas endógenas. A hidrólise prolongada, no entanto, pode resultar numa redução do valor nutricional da silagem (Oetterer, 1999; Raa \& Njaa, 1989; Nunes, 1999; Viana et al.,1999). Para evitar a hidrólise excessiva durante estocagem prolongada, as enzimas presentes no pescado podem ser inativadas pelo aquecimento da matéria-prima por 5 minutos, a $60^{\circ} \mathrm{C}$, antes da ensilagem, resultando na redução de 15\% no nível de aminoácidos livres após 90 dias, quando comparada com uma silagem que não foi aquecida (Viana et al., 1996).

As condições do substrato utilizado estão diretamente relacionadas à qualidade da silagem resultante. Se a silagem é preparada a partir de material em processo de decomposição, o produto obtido se apresentará com níveis elevados de degradação lipídica (FAO, 2003a ).

Segundo Oetterer (2002) o aproveitamento do resíduo deve ser imediato, assim que é escoado das mesas processadoras. Após a evisceração, se manual, as partes sólidas devem ser separadas, homogeneizadas e tratadas por ácidos.

A silagem pode ser utilizada após uma semana e até um mês de estocada, apresentando composição semelhante à da matéria-prima, alta digestibilidade com presença integral dos aminoácidos constituintes do pescado e, portanto, ser destinada ao uso como ração. A estocagem, se mais longa, constituiria um ponto crítico nutricional, pois os aminoácidos e os lipídios passam a sofrer alterações (Oetterer,1999). 


\subsection{Material e métodos}

\subsubsection{Matéria-prima}

A matéria-prima para obtenção da silagem química de pescado, constituiu-se de resíduo de tilápias do Nilo (Oreochromis niloticus) provenientes do cultivo comercial, na região de Piracicaba, SP.

O resíduo de tilápias utilizado foi proveniente da filetagem de 40 exemplares de tilápias (com peso total de $21 \mathrm{~kg}$ e peso médio dos exemplares de $500 \mathrm{~g}$ ), realizada nos laboratórios do Setor de Processamento de Alimentos do Departamento de Agroindústria, Alimentos e Nutrição da ESALQ/USP, conforme estabelecido por Oetterer (2002). O material residual recuperado para elaboração da silagem pesava $15 \mathrm{~kg}$ e era constituído de 7,7 $\mathrm{kg}$ de cabeças, 2,5 $\mathrm{kg}$ de nadadeiras, 1,5 $\mathrm{kg}$ de vísceras e 3,5 $\mathrm{kg}$ de coluna vertebral, pele e tecidos aderidos.

\subsubsection{Metodologia de elaboração da silagem}

A matéria- prima descrita no item 4.1 foi fragmentada em triturador, equipamento elétrico modelo ML-4.0/Weg- $\mu$ line, totalizando $15 \mathrm{~kg}$. Em seguida foi homogeneizada, pesada e distribuída uniformemente em 3 recipientes de plástico rígido. Adicionou-se o antioxidante BHT (hidroxibutilanisol), dissolvido em álcool etílico na concentração de 0,02g/100g (BRASIL, 1998) e a mistura de ácidos (propiônico e fórmico na proporção $1: 1$ ), na relação de $3 \%$ do volume da solução ácida para a massa de resíduo. As duas soluções foram adicionadas manualmente, ao material homogeneizado, sob constante revolvimento, obtendo-se a silagem química de tilápia, na qual foi feito o controle diário do $\mathrm{pH}$ para que permanecesse próximo de 4,0. As silagens

permaneceram ao ambiente $\left(27^{\circ} \mathrm{C} \pm 1^{\circ} \mathrm{C}\right)$ por 72 horas, quando foram submetidas às análises de composição química. Na Figura 1 é apresentado o fluxograma de obtenção da silagem química de tilápia. 
Matéria-prima

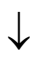

Trituração/homogeneização

$\downarrow$

Adição de antioxidante BHT

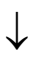

Adição dos ácidos propiônico e fórmico

$\downarrow$

Revolvimento da biomassa

$\downarrow$

Controle do $\mathrm{pH}$

$\downarrow$

Silagem química pastosa

Figura 1- Fluxograma de obtenção da silagem química de tilápia.

\subsubsection{Determinação do pH}

Utilizou-se o potênciometro digital, marca Digimed, expressando resultados em duas casas decimais. As determinações foram feitas, a cada 24 horas, durante 72 horas.

\subsubsection{Análise sensorial de acompanhamento}

Foi realizada observando, durante 24 horas, o comportamento da biomassa a partir da elaboração e adição de ácidos, quanto aos parâmetros de aparência, como formação de massa uniforme, coloração marrom clara e odor ácido característico.

\subsubsection{Composição centesimal}

Foram realizadas análises para determinação da composição centesimal, para a silagem química de tilápia. Todas as análises foram realizadas em triplicata e de acordo com A.O.A.C. (1990). A umidade foi determinada através do método gravimétrico, em estufa a $105^{\circ} \mathrm{C}$ até peso constante. $\mathrm{O}$ teor de cinza foi medido pelo método gravimétrico, 
em mufla a $550^{\circ} \mathrm{C}$ e incineração da matéria orgânica em bico de Bunsen. A análise de proteínas foi realizada através do método Micro-Kjeldhal, com digestão em bloco digestor e em seguida destilação no destilador acoplado e titulação com ácido sulfúrico 0,02N. A fração lípidica foi obtida pelo extrator Soxhlet, utilizando-se como solvente o éter de petróleo, seguido de aquecimento em estufa até evaporação total do solvente.

\subsubsection{Determinação da composição de aminoácidos}

Os aminoácidos foram determinados após digestão ácida e básica e separados por cromatogafia de troca iônica (HPLC). As amostras foram analisadas por cromatografia líquida, em colunas de resina de troca catiônica e derivação pós-coluna com ninidrina, em auto analisador. Para a quantificação dos aminoácidos, as amostras foram hidrolisadas com $\mathrm{HCl} 6 \mathrm{~N}$, por 22 horas a $110^{\circ} \mathrm{C}$, de acordo com método descrito por Moore \& Stein (1963).

$\mathrm{O}$ triptofano foi determinado após hidrólise enzimática com Pronase a $40^{\circ} \mathrm{C}$ por 24 horas, seguido de reação colorimétrica com 4-Dimetil-Amino-Benzaldeído (DAB) em ácido sulfúrico $21,2 \mathrm{~N}$ e leitura a $590 \mathrm{~nm}$. O teor de triptofano foi calculado a partir de uma curva padrão, segundo Spies (1967). As análises foram realizadas pelo laboratório CBO Assessoria \& Análise, localizado em Campinas, São Paulo.

\subsubsection{Determinação do escore químico de aminácidos essenciais}

A determinação do escore químico foi feita conforme Sgarbieri (1987), através da relação entre o teor de cada aminoácido essencial com o teor do aminoácido correspondente de uma proteína padrão. Nesta pesquisa, o escore da silagem ácida de tilápia foi calculado utilizando como fonte protéica, o padrão estabelecido pela FAO (1985).

\subsection{Resultados e Discussão}

A partir do experimento realizado pode-se afirmar que, conforme já exposto por Ottati et al. (1990), o processo para a obtenção do ensilado é simples, prático e 
econômico, não requerendo equipamentos e procedimentos custosos, como os empregados na produção de farinha de peixe.

Ainda que, diversos pesquisadores (Lessi et al., 1989; Lupin, 1989, MoralesUlloa, 1994; Valério, 1994; Sales,1995; Espindola-Filho, 1999; Vidotti, 2001, Ximenes Carneiro, 1991) já tenham realizado pesquisas de produção e utilização da silagem com este processo, para várias espécies, ao contrário do que acontece em outros países, a silagem não tem sido produzida comercialmente pelas indústrias brasileiras. Podemos apontar como motivos para a não utilização, a dificuldade de se obter uma oferta constante da mesma e que apresente um padrão de qualidade.

Pelo exame visual das silagens, observou-se que a liquefação da massa homogênea iniciou-se entre o $2^{\circ}$ e $3^{\circ}$ dias e aumentou gradativamente até o final do experimento, resultando num produto com característica líquido-pastosa, corroborando o observado por Valério (1994). Este aspecto é atribuído à contínua hidrólise protéica que acontece na silagem devido à ação das enzimas proteolíticas naturalmente presentes no pescado, principalmente nas vísceras e/ou adicionadas (Haard et al., 1985; Kompiang, 1981).

Durante 72 horas de produção das silagens foi observada alteração da massa, levando à formação de uma massa pastosa, de coloração marrom claro e aroma ácido. Estas características da silagem química de tilápias estão de acordo com o que foi descrito para silagens de várias espécies de pescado por Disney et al. (1977); Haard et al. (1985); Ottati et al. (1990); Moraes-Ulloa (1994); Taterson \& Windsor (1974 ) e Valério (1994).

$\mathrm{O}$ pH da silagem está apresentado na Tabela 1. A silagem ácida apresentou valor final para $\mathrm{pH}$, de 4,12. 
Tabela 1. Valores de pH da matéria-prima e da silagem ácida de tilápias.

\begin{tabular}{ccccc}
\hline & \multicolumn{5}{c}{ Dias } \\
\hline & Início & 1 & 2 & 3 \\
Matéria-prima & 6,70 & - & - & - \\
Silagem & - & 3,80 & 4,00 & 4,12 \\
\hline
\end{tabular}

$\mathrm{O}$ pH ácido (abaixo de 4,5) aliado à ação bactericida do ácido propiônico garantiu a qualidade da silagem ácida durante o período experimental (Valério, 1994; Raa \& Gilberg, 1982).

É interessante ressaltarmos a diferença dos valores encontrados nas análises químicas, realizadas para a silagem elaborada neste trabalho e os resultados de outras pesquisas para caracterização de silagens produzidas com o mesmo tipo de matériaprima e apresentados por Vidotti, 2001.

Sales (1995) atesta que o resíduo pode se alterar conforme o período (sazonal) de coleta e a dextreza dos funcionários da indústria, além dos aspectos zootécnicos de produção da tilápia. Nesta pesquisa, a introdução do antioxidante colaborou para a padronização desta, bem como a utilização do manejo pós captura, conforme preconizado por Oetterer (2002).

Pouco consta na literatura consultada a respeito da utilização de antioxidantes na elaboração de silagem, para qualquer espécie de pescado. Bobbio \& Bobbio (2001) relatam que o BHT(hidroxibutilanisol) é o antioxidante mais eficiente em gorduras animais. Atualmente, os antioxidantes industrialmente mais utilizados para inibir o processo oxidativo dos lipídios na farinha de peixe são o BHT e o Etoxiquin (1,2dihydro-6-ethoxy-2,2,4-trimethylquinolina).

A Tabela 2 apresenta os macro componentes da silagem química de tilápia. 
Tabela 2. Composição centesimal da silagem de tilápia (valores expressos em g/100g)

\begin{tabular}{lcc}
\hline Componentes * & $\begin{array}{c}\text { Matéria úmida } \\
(\mathrm{g} / 100 \mathrm{~g})\end{array}$ & $\begin{array}{c}\text { Matéria seca } \\
(\mathrm{g} / 100 \mathrm{~g})\end{array}$ \\
\hline Matéria Seca & - & $21,68 \pm 0,83$ \\
Umidade & $78,32 \pm .0,81 * *$ & - \\
Cinza & $4,17 \pm 0,23$ & $19,23 \pm 0,24$ \\
Proteína Bruta & $12,85 \pm 0,65$ & $59,27 \pm 0,64$ \\
Extrato Etéreo & $3,89 \pm 0,35$ & $18,40 \pm 0,33$ \\
\hline
\end{tabular}

*média de 3 repetições.

**desvio padrão da média.

O resultado obtido para o teor de proteína bruta da silagem ácida está próximo ao apresentado por Heras et al. (1994), da ordem de 57,75 g/100g e Hossain et al. (1997) para silagem ácida, $56,50 \mathrm{~g} / 100 \mathrm{~g}$. Entretanto, se distancia dos resultados obtidos por Johnson et al. (1985), 37,10 g/100g.

Os macro componentes encontrados por Vidotti (2001) para a silagem química de tilápia produzida também, a partir de resíduo de filetagem, em 31,38 g/100g de matéria seca, foram os seguintes: $68,62 \mathrm{~g} / 100 \mathrm{~g}$ de umidade, $5,13 \mathrm{~g} / 100 \mathrm{~g}$ de cinza, 13,49 $\mathrm{g} / 100 \mathrm{~g}$ de proteína bruta e $10,85 \mathrm{~g} / 100 \mathrm{~g}$ de extrato etéreo.

A Tabela 3, apresenta valores de composição centesimal para a silagem de pescado produzida a partir de diferentes matérias-primas. 
Tabela 3. Composição química de diferentes tipos de silagem ácida de pescado

\begin{tabular}{ccccc}
\hline Substrato & Origem/espécie & Proteína & Ext. Etéreo & Cinza \\
\hline "By-catch" & Tailândia & 58,1 & 4,2 & 30 \\
& Inglaterra & 66,5 & 16,6 & 11,7 \\
& Cuba & 52,6 & 10,4 & 11,9 \\
\multirow{2}{*}{ Resíduo } & Arenque (Clupea harengus) & 48,3 & 28,2 & 125 \\
& Atum (Tunnus spp) & 69,9 & 12,2 & 10,5 \\
& Bacalhau (Gadus morhua) & 68,1 & 2,1 & 19 \\
\hline
\end{tabular}

Nota: valores expressos em $\mathrm{g} / 100 \mathrm{~g}$ de matéria seca.

Fonte: FAO (2003b)

Comparando-se os resultados encontrados nesta pesquisa e expostos na Tabela 2 e os valores da Tabela 3, pode-se afirmar que a composição da silagem é diretamente relacionada com o material que lhe deu origem. Portanto, para uma possível utilização industrial, será necessário uma padronização, bem como a indicação da composição da silagem produzida.

Esta exigência pode ser futuramente facilitada em decorrência do aumento da participação da aqüicultura, principalmente intensiva, na produção do pescado (Valenti, 2000) fornecendo um produto mais homogêneo quanto à composição, devido a padronização da alimentação com o uso de rações balanceadas e quanto ao tamanho dos peixes, facilitando o ajuste dos equipamentos pelas indústrias beneficiadoras.

As Tabelas 4 e 5 apresentam os teores de aminoácidos da silagem de tilápias e o escore químico dos aminoácidos essenciais. 
Tabela 4. Aminoácidos contidos na silagem química de tilápia comparados com o padrão da $\mathrm{FAO}$, em $\mathrm{g} / 100 \mathrm{~g}$ de proteína

\begin{tabular}{lcc}
\hline Aminoácidos * & $\mathrm{G} / 100 \mathrm{~g}$ & $(\mathrm{FAO}) \mathrm{g} / 100 \mathrm{~g}$ \\
\hline Ácido aspartico & 10,92 & - \\
Treonina & 4,08 & 4,00 \\
Serina & 3,66 & - \\
Ácido glutâmico & 12,02 & - \\
Prolina & 5,60 & - \\
Glicina & 8,82 & - \\
Alanina & 7,52 & - \\
Cistina & 1,54 & - \\
Valina & 5,40 & 5,00 \\
Metionina & 4,34 & 3,50 \\
Isoleucina & 6,46 & 4,00 \\
Leucina & 7,00 & 7,00 \\
Fenilalanina + Tirosina & 6,70 & 6,00 \\
Lisina & 6,66 & 5,50 \\
Histidina & 2,80 & - \\
Arginina & 5,80 & - \\
Triptofano & 0,72 & 1,00 \\
\hline
\end{tabular}

*Média de 3 repetições.

**Fonte: FAO (1985) 
Tabela 5. Escore químico dos aminoácidos essenciais contidos na silagem química de tilápia comparados com o padrão da FAO

\begin{tabular}{lcc}
\hline Aminoácidos & $\begin{array}{c}\text { Silagem } \\
(\mathrm{g} / 100 \mathrm{~g})\end{array}$ & $\begin{array}{c}\text { FAO/WHO } \\
(\mathrm{g} / 100 \mathrm{~g})\end{array}$ \\
\hline Triptofano & 0,72 & 1,00 \\
Lisina & 1,21 & 5,50 \\
Histidina & 1,40 & 2,00 \\
Arginina & 1,16 & 5,00 \\
Treonina & 1,02 & 4,00 \\
Valina & 1,08 & 5,00 \\
Metionina & 1,24 & 3,50 \\
Isoleucina & 1,61 & 4,00 \\
Leucina & 1,00 & 7,00 \\
Fenilalanina+Tirosina & 1,56 & 4,29 \\
\hline
\end{tabular}

**Fonte: FAO (1985)

O ácido glutâmico, a leucina e a lisina são os aminoácidos encontrados em maior concentração para a silagem elaborada nesta pesquisa (Tabela 4), assim como os encontrados por Jackson et al. (1984a); Johnson et al. (1985); Hassan \& Heath (1987); Morales-Ulloa \& Oetterer (1997) e Vidotti $(2001,2003)$.

A silagem de tilápias apresentou valores iguais ou maiores ao padrão da FAO (1985) para todos os aminoácidos essenciais, com exceção do triptofano, que se apresenta $72 \%$ do teor do padrão (Tabela 5). Os valores mais elevados para os aminoácidos essenciais foram para a leucina e para a lisina.

Ainda entre os aminoácidos essenciais, o triptofano apresentou-se em menor concentração para a silagem elaborada, corroborando Strom \& Eggum (1981) e Espe et al. (1989). De acordo com Fagbenro \& Bello-Olusoji (1997) o triptofano é lábil em condições ácidas. 
O escore químico obtido na presente pesquisa é semelhante ao encontrado por Vidotti (2001), o aminoácido crítico (limitante) foi o triptofano (Tabela 5). No entanto, deve-se considerar como aminoácido limitante apenas o que estiver 30\% abaixo das exigências mínimas para peixes. De acordo com os limites discutidos por Tacon (1994), a silagem de pescado elaborada não apresenta deficiência em nenhum aminoácido essencial.

A Tabela 6 apresenta os aminoácidos essenciais presentes na silagem de tilápia e os aminoácidos essenciais contidos na farinha de peixe de marca comercial chilena, utilizada por Portz (2001b) para comparação em pesquisa sobre fontes protéicas alternativas. A silagem de tilápia apresentou todos os aminoácidos essenciais em maior quantidade do que a farinha de peixe.

Tabela 6. Aminoácidos essenciais contidos na silagem química de tilápia comparados com os encontrados na farinha de peixe

\begin{tabular}{lcc}
\hline Aminoácidos & $\begin{array}{c}\text { Silagem } \\
(\mathrm{g} / 100 \mathrm{~g})\end{array}$ & $\begin{array}{c}\text { Farinha de peixe } \\
(\mathrm{g} / 100 \mathrm{~g})\end{array}$ \\
\hline Triptofano & 0,72 & 0,42 \\
Lisina & 6,66 & 5,79 \\
Histidina & 2,80 & 1,38 \\
Arginina & 5,80 & 4,39 \\
Treonina & 4,72 & 2,93 \\
Valina & 5,40 & 3,93 \\
Metionina & 4,34 & 1,62 \\
Isoleucina & 6,46 & 3,20 \\
Leucina & 7,00 & 4,81 \\
Fenilalanina+Tirosina & 6,70 & 6,19 \\
\hline
\end{tabular}

** Fonte: Portz (2001b) 
Conforme preconizado por Stron \& Eggum (1981) os teores de lisina, cistina e metionina devem ser observados, prioritariamente, na elaboração de rações para peixes. Nenhum desses aminoácidos apresentou-se deficiente na silagem elaborada nesta pesquisa.

Cyrino (2000) relata que as diversas fontes protéicas disponíveis no mercado para formulação das rações não possuem o mesmo valor nutricional nem a composição de aminoácidos exigidos pelos peixes, tanto qualitativamente quanto quantitativamente. Na silagem elaborada, a composição de aminoácidos e a concentração de proteína bruta mostraram-se adequadas (Tabelas 2, 4 e 5) porém, para que se possa estimar a qualidade da silagem como fonte protéica e se proceder à formulação de rações ecônomicas e eficientes são necessários ensaios de digestibilidade "in vivo".

\subsection{Conclusões}

A silagem ácida de resíduo de tilápia apresentou-se pastosa e homogênea a partir de $24 \mathrm{~h}$ da elaboração, sob temperatura ambiente de $26-30^{\circ} \mathrm{C}$.

A silagem apresenta $59,27 \%$ de proteína bruta na matéria seca e todos os aminoácidos essenciais em teores semelhantes ou maiores aos preconizados pelo padrão FAO, à exceção do triptofano.

Os aminoácidos leucina e lisina apresentaram-se com os teores mais elevados, de 7 e $6,66 \mathrm{mg} / 100 \mathrm{~g}$ de proteína, respectivamente.

Os aminoácidos treonina, valina, metionina, isoleucina e lisina apresentaram-se com teores mais elevados que o padrão da FAO.

Os resultados indicam uma possível utilização da silagem preparada, a partir do resíduo de processamento da Tilápia do Nilo (Oreochromis niloticus), na formulação de ração para cultivo de peixes. 


\section{RENDIMENTO E QUALIDADE FÍSICO-QUÍMICA DO ÓLEO DE SILAGEM DE TILÁPIA DO NILO (Oreochromis niloticus) OBTIDO PELOS MÉTODOS DE CENTRIFUGAÇÃO, SOXHLET E BLIGH \& DYER = EVALUTION OF THE PHYSICAL-CHEMICAL QUALITY OF THE NILE TILAPIA (Oreochromis niloticus) SILAGE OIL THROUGH CENTRIFUGATION, SOXHLET AND BLIGH \& DYER METHODS}

\section{Resumo}

A utilização da silagem de pescado como fonte protéica para ração animal é uma forma de diminuir os custos de produção. É necessário que se estabeleçam técnicas para remoção do óleo presente na silagem, com a finalidade de aumentar a estabilidade do produto e seu valor comercial. A oxidação dos lipídios presentes pode levar à formação de peróxidos, que podem complexar as proteínas, com conseqüente destruição dos aminoácidos. Esta pesquisa buscou estabelecer a melhor via de extração do óleo presente na silagem ácida de tilápia do Nilo (Oreochromis niloticus), bem como caracterizar o óleo obtido. A fração lipídica foi extraída por três métodos de extração, a saber, centrifugação $(3500 \times$ G/30 min), Soxhlet (AOAC,1990) e Bligh \& Dyer (1969). Os resultados para rendimento e índice de peróxido foram, respectivamente, $65,53 \%$ e zero $\mathrm{mEq} / 1000 \mathrm{~g}$ de $\mathrm{O}_{2}, 44,27 \%$ e $25 \mathrm{mEq} / 1000 \mathrm{~g}$ de $\mathrm{O}_{2}, 46,87 \%$ e $0,00 \mathrm{mEq} / 1000 \mathrm{~g}$ de $\mathrm{O}_{2}$. O óleo de tilápia contém 28,$6 ; 16,3$ e $3,1 \mathrm{mg} / 100 \mathrm{~g}$ de ácido oléico, linoléico e linolênico, respectivamente. A centrifugação demonstrou ser a melhor metodologia de extração, por preservar as características físico-químicas do óleo e propiciar maior rendimento. O conteúdo de lipídios na silagem de tilápias, com base na matéria úmida é de $3,99 \mathrm{~g} / 100 \mathrm{~g}$, com a retirada da fração lipídica através da centrifugação, restou na 
amostra apenas $1,54 \mathrm{~g} / 100 \mathrm{~g}$ de lipídios, o que é considerado um nível aceitável para inclusão em rações para animais. A utilização da silagem de pescado como substituto de ingredientes protéicos em rações para organismos aquáticos surge como alternativa para solucionar os problemas de ordem sanitária e ambiental causados pela falta de destino adequado dos resíduos gerados pela indústria do pescado, além de diminuir os custos com alimentação e conseqüentemente os custos de produção do pescado, já que os gastos com a alimentação correspondem a aproximadamente $60 \%$ do custo total. A digestibilidade aparente é uma das principais ferramentas para avaliar o potencial do ingrediente a ser utilizado em rações para peixes. Este trabalho teve por objetivo determinar os coeficientes de digestibilidade aparente (CDA) da energia, nutrientes e aminoácidos da silagem ácida (SA), silagem biológica (SB) e silagem enzimática (SE) pela tilápia do Nilo (Oreochromis niloticus) com peso médio de 94,54 $\pm 12,66 \mathrm{~g}$. Foram encontrados valores de energia digestível de: 4041,32; 3663,95 e 3394,20 Kcal/kg para SA, SB e SE, respectivamente. Foram obtidos valores de CDA de: 92,01; 89,09 e 93,66\% para proteína bruta, 89,$86 ; 87,61$ e $90,10 \%$ para cinza, 82,$52 ; 78,98$ e $82,96 \%$ para matéria seca, 81,$72 ; 73,99$ e $80,27 \%$ para cálcio e 77,$86 ; 79,21$ e $81,46 \%$ para o fósforo na SA, SB e SE, respectivamente. O CDA médio dos aminoácidos foi de: 91,83; 90,76 e $94,61 \%$ para SA, SB e SE, respectivamente. Os resultados obtidos demonstram a possibilidade da utilização da SA, SB e SE como ingrediente protéico em rações balanceadas para aqüicultura, como substituto parcial da farinha de peixe.

\section{Summary}

Fish silage can be used as a proteic source for animal feed as a form of decreasing production costs. For the use of the silage, oil-removing techniques are necessary in order to increase the stability of the product as well as its commercial value. Lipid oxidation may cause peroxide formation, which can produce complex proteins with a consequent destruction of amino acids. The present work tried to determine the best form of extracting the oil from the acid silage of Nile tilapia (Oreochromis niloticus) and to caracterize the silage oil. The lipid fraction was extracted by three 
extraction methods: centrifugation $\left(3500 \times \mathrm{G} \cdot 30 \mathrm{~min}^{-1}\right)$, Soxhlet (AOAC, 1990) and Bligh \& Dyer (1969). The results for yield and peroxide value were, respectively, $65.53 \%$ and $0.00 \mathrm{mEq} \cdot 1000 \mathrm{~g}^{-1}$ of $\mathrm{O}_{2}, 44.27 \%$ and $25.00 \mathrm{mEq} \cdot 1000 \mathrm{~g}^{-1} \mathrm{of} \mathrm{O}_{2}, 46.87 \%$ and $0.00 \mathrm{mEq} \cdot 1000 \mathrm{~g}^{-1}$ of $\mathrm{O}_{2}$. The lipid fraction showed 28,$60 ; 16,30$ and $3,10 \mathrm{mg} \cdot 1000 \mathrm{~g}^{-1}$ of oleic, linoleic and linolenic acids, respectively. Centrifugation proved to be the best extraction methodology due to the preservation of the physical-chemical characteristics of the oil and greater yield. The lipid content of the tilapia silage, on a fresh matter basis, was $3.99 \mathrm{~g} \cdot 100 \mathrm{~g}^{-1}$. With the removal of the lipid fraction by centrifugation, only 1.54 $\mathrm{g} \cdot 100 \mathrm{~g}^{-1}$ of lipids could be found in the sample, which is considered an acceptable level for its inclusion in animal feed.The use of the fish silage as substitute of protein ingredients in feed for aquatic organisms is an alternative to solve sanitary and environmental problems caused by the lack of an adequate destination for the residues generated by the fishing industry. It would also lower the costs with feed, and consequently the fish production costs, since the expenses with the feed account for approximately $60 \%$ of the total cost. Apparent digestibility is one of the main tools to evaluate the potential of an ingredient to be used in fish foods. Based on this, this work had the objective of determining the apparent digestibility coefficients (ADC) of the energy, nutrients and amino acids of acid silage (AS), biological silage (BS) and enzymatic silage (ES) for the Nile tilapia (Oreochromis niloticus) with average weight $94.54 \pm 12.66 \mathrm{~g}$. The digestible energy values found were: $4041.32 ; 3663.95$ and 3394.20 Kcal. $\mathrm{Kg}^{-1}$ for AS, BS and ES, respectively. ADC values were: 92.01; 89.09 and $93.66 \%$ for raw protein, 89.86; 87.61 and $90.10 \%$ for ash, 82.52; 78.98 and $82.96 \%$ for dry matter, $81.72 ; 73.99$ and $80.27 \%$ for calcium and $77.86 ; 79.21$ and $81.46 \%$ for phosphor for AS, BS and ES, respectively. The average ADC of amino acids was: 91.83; 90.76 and $94.61 \%$ for AS, BS and ES, respectively. The results demonstrate the possibility for the use of AS, BS and ES as a protein ingredient in balanced feed for the fishing industry as a partial substitute of fish meal. 


\subsection{Introdução}

Uma forma de minimizar os problemas ambientais gerados pela grande quantidade de resíduo de pescado, é sua transformação em um produto que possa ser incorporado como ingrediente em rações animais (Ristic et al., 2002). Além do material residual que é descartado pela indústria, existe também aquele que é perdido mesmo antes de chegar às plantas processadoras devido ao manejo, transporte e armazenamento inadequados praticados durante e após a captura (Zahar et al., 2002).

Portanto, devido a valorização emergente do aproveitamento do resíduo do setor pesqueiro marinho e da piscicultura, gerada pelas necessidades de gerenciamento ambiental, busca do desenvolvimento sustentável, redução de custos de produção do pescado brasileiro a ser ofertado para a comercialização e industrialização e ainda, o aumento dos benefícios da agroindústria do pescado cultivado, faz-se necessário o desenvolvimento de tecnologias que tenham o objetivo de aproveitar este material, rico em proteína e lipídios, e a inserção deste na cadeia produtiva do pescado (Oetterer, 2002).

Uma alternativa viável seria destinar o resíduo para a fabricação da silagem de pescado, por ser um produto de fácil elaboração e que não exige alto investimento. $\mathrm{O}$ produto final é estável, com boa qualidade nutritiva e características antimicrobianas, podendo, portanto, ser de grande utilidade para a alimentação animal (Berenz, 1994).

A elaboração da silagem a partir de resíduo da comercialização ou do processamento do pescado, visando sua utilização como ingrediente em rações para a aqüicultura, tem sido, nos últimos tempos, amplamente estudada. Muitos autores acreditam que devido a semelhança desta fonte protéica com a matéria-prima, a silagem tenha elevado potencial para a utilização na aqüicultura. Outros se apóiam no baixo custo, principalmente quando comparada à farinha de peixe (Das et al., 1993; Disney et al., 1977; Fagbenro, 1994; Fagbenro et al., 1994, Fagbenro \& Bello-Olusoji, 1997; Fagbenro \& Jauncey, 1995a, 1995b, 1998; Goddard \& Al-Yahyai, 2001; Neethiselvan et al., 2001; Vidotti et al., 2003). 
O teor de lipídios é um ponto importante para a investigação da qualidade da silagem, pois como os ácidos graxos que constituem o óleo de pescado são altamente insaturados, estes podem oxidar facilmente afetando a qualidade nutricional do produto, indisponibilizando proteínas e aminoácidos ou tornando o produto impalatável (FAOa, 2003).

Portanto, devido a esses fatores, existem autores que defendem a retirada da fração lipídica durante a elaboração da silagem para a obtenção de um produto uniforme e de maior estabilidade (Disney, 1977; Haard et al., 1985; Kompiang, 1981; Potter et al. 1979; Raa \& Gilberg, 1982; Tatterson \& Windsor, 1974)

O objetivo desta pesquisa foi otimizar o aproveitamento do resíduo do processamento das tilápias, através da obtenção da silagem como subproduto e tornar a silagem de tilápias mais estável, através da remoção de parte do teor lipídico desta. Como objetivos específicos pretendeu-se extrair a fração lipídica pelas vias: centrifugação, Soxhlet e Bligh \& Dyer e caracterizar o óleo obtido quanto a qualidade físico-química.

\subsection{Revisão de literatura}

\subsubsection{Fração lipídica presente na silagem}

A silagem de pescado pode ser utilizada como fonte proteíca alternativa na formulação de rações para monogástricos. Entretanto, devido a oxidação lipídica que pode comprometer o valor nutricional da ração, recomenda-se a retirada da fração lipídica durante a elaboração da silagem para que se obtenha um produto uniforme e de maior estabilidade (Disney, 1977; Raa \& Gilberg, 1982; Tatterson \& Windsor , 1974)

A composição final da silagem varia, consideravelmente, com o tipo de matéria-prima empregada, particularmente quanto ao teor de lipídios que é variável com a estação da captura (Brown \&Sumner, 1985; Disney et al., 1977; Haard et al., 1985).

Fator importante de deterioração da qualidade das silagens armazenadas por longos períodos, é o processo de oxidação lipídica, resultando em alterações de sabor, cor, textura, valor nutricional e produção de componentes tóxicos (Sales, 1995). O 
processo oxidativo pode ser acelerado se a silagem de pescado estiver em contato com a luz e o ar (FAO, 2003a).

Kompiang (1981) destaca que o valor nutricional da silagem é afetado negativamente, com o aumento do tempo de armazenamento. Para o autor há uma relação direta do escurecimento provocado por reações dos lipídios com a perda do valor nutritivo.

Sales (1995) relata que quando as proteínas são expostas a lipídios peroxidados, podem complexar-se com proteínas através de associações e/ou ligações de hidrogênio, causando perda do valor nutritivo.

A oxidação de lipídios pode levar à formação de peróxidos, que se complexam com as proteínas, através de ligações físicas e covalentes. Ligações covalentes entre produtos oxidados e proteínas podem destruir aminoácidos como o triptofano, oxidar a metionina e ligar a lisina a outros compostos tornando estes aminoácidos indisponíveis (Nelson \& Cox, 2000).

Disney et al. (1977) discutem as alterações que ocorrem com os lipídios durante o armazenamemto da silagem. Mencionam que o aumento do conteúdo de ácidos graxos livres, indica a hidrólise dos glicerídeos, enquanto alterações oxidativas causam escurecimento. Os autores recomendam que, para manter a qualidade do produto, deve haver uma rápida remoção da gordura, pois as maiores transformações ocorrem no início do processo e são dependentes da temperatura.

Em pesquisa desenvolvida por Haard et al. (1985), preparou-se silagem de resíduo de bacalhau do Atlântico (Gadus morhua) utilizando 3,5\% (v/p) de ácido fórmico. A silagem obtida tornou-se líquida e homogênea em 36 a 48 horas à temperatura de $20{ }^{\circ} \mathrm{C}$, embora o óleo e os componentes proteícos continuassem sofrendo hidrólise por vários meses. Segundo os autores, a manutenção dos componentes lipídicos da silagem para aumentar a porção energética, em formulações para ração animal, é indesejável por causa da degradação lipídica desta fração. 


\subsubsection{Utilização da fração lipídica de pescado}

Os peixes são um importante constituinte da dieta humana de inúmeros grupos populacionais, já que são uma fonte de diversos componentes, com significativo valor nutricional, como proteínas de alta qualidade, vitaminas, sais minerais e lipídeos, além de serem a maior reserva de ácidos graxos polinsaturados, especialmente o eicosapentaenóico - EPA (C20:5) e o docosahexaenóico - DHA (C22:6), da série $\omega$-3, aos quais são atribuídos numerosos benefícios ao organismo humano (Stansby,1969; Belda \& Pourchet-Campos,1991; Minazzi-Rodrigues \& Penteado,1991; Badolato et al., 1994).

Ômega 3 ou série n-3 são denominações utilizadas para os ácidos graxos poliinsaturados que possuem a primeira dupla ligação na posição 3. Os principais representantes são o $\alpha$-linolênico e seus derivados DHA e EPA. Os ácidos graxos $\omega 6$ têm sua primeira dupla ligação entre o sexto e o sétimo átomo de carbono, contando-se a partir do carbono do lado oposto ao carbono carboxílico. Tanto os ácidos graxos tipo $\omega 3$ quanto os $\omega 6$ apresentam efeitos hipotensores e reduzem os níveis de LDL (Turatti, 2000).

O mais importante dos ácidos graxos polinsaturados $\omega-3$ parece ser o EPA, que apresenta potencial anti-agregatório, resultando na inibição competitiva da síntese trombótica "eicosanóide tromboxane" (Bronsgeest-Shoute et al., 1981; Budowski, 1981) ou resulta em aumento da produção de prostaciclinas, as quais são agentes antiagregatórios (Goodnight et al., 1981). Além do EPA, destacam-se o ácido araquidônico e o DHA como precursores dos eicosanóides (Turatti, 2000).

O alto teor de ácidos graxos poliinsaturados da família ômega-3 presentes no óleos de pescado conferem a esses óleos uma notável importância e sugerem seu emprego para propósitos farmacêuticos. Contudo, deve-se levar em consideração, a velocidade com que tais óleos oxidam e a necessidade de estender a estabilidade dos mesmos.

Os ácidos graxos essenciais são utilizados em diversos países para a prevenção e tratamento de diversos distúrbios na saúde humana. São empregados em suplementos nutricionais, nutrição infantil, alimentos medicinais e funcionais, nutrição parenteral e 
como ativos e veículos farmacêuticos. A sua indicação por médicos tem sido cada vez mais freqüente, inclusive no Brasil, e os produtos disponíveis estão cada vez mais aperfeiçoados (Pacchioni, 1999).

Os óleos de peixe costumam conter cerca de 30\% de ácidos essenciais ômega-3, sendo, aproximadamente, 18\% de EPA e 12\% de DHA (Pacchioni, 1999).

Diante da insuficiência de dados experimentais sobre efeitos benéficos e colaterais devidos à ingestão dos ácidos graxos ômega-3, o "Food and Drug Administration" (FDA) proibiu a comercialização de óleos de peixe como medicamento nos Estados Unidos, enquadrando-os na categoria de suplemento alimentar (Badolato et al., 1991).

Os óleos de peixe têm sido utilizados para elaboração de alimentos há muito tempo, principalmente margarina (Bimbo,1987) porque são de considerável interesse bioquímico, metabólico, nutricional e farmacêutico (Stansby,1969). As pesquisas científicas têm se intensificado neste assunto justamente pelos numerosos benefícios a eles atribuídos, em particular a seus ácidos graxos EPA e DHA (Ackman \& McLeod,1988).

No Brasil, a oferta no comércio de suplementos alimentares a base de óleo de peixe, contendo os ácido EPA e DHA encapsulados, vem crescendo ultimamente, bem como as solicitações de análises no Instituto Adolfo Lutz para fins de registro de novas marcas desses produtos no Ministério da Saúde. De acordo com o declarado pelos interessados, o óleo, geralmente de sardinha, é importado da Inglaterra e submetido ao encapsulamento no Brasil. A fórmula convencional garante que o produto contém $180 \mathrm{mg}$ de EPA e 120mg de DHA por grama. Em alguns casos, há adição de vitamina E ou tocoferol como antioxidante (Badolato et al., 1991).

A indústria do pescado representa um vasto potencial, pois seus descartes podem ser facilmente transformados em produtos com aproveitamento mercadológico. Atualmente, durante a produção de farinha de pescado é obtido, também, o óleo de pescado através de processos que envolvem aquecimento e prensagem do resíduo. $\mathrm{O}$ óleo de pescado assim obtido possui baixa qualidade e não pode ser utlizado para consumo humano. 
Os numerosos efeitos benéficos para a saúde humana, tanto adulta quanto infantil, descritos para os óleos de pescado, ricos em ácidos graxos $\omega$-3 e $\omega$-6, têm motivado um grande número de cientistas a melhorar as características organolépticas e os procedimentos de extração deste produto, sem alterar suas características químicas, especialmente seu conteúdo em ácidos graxos.

No Brasil, a sardinha é o peixe mais popular, representando $50 \%$ da comercialização de pescado no Entreposto Terminal de São Paulo (CEAGESP), o maior do país. Na Região Sudeste, a espécie mais explorada é a sardinha-verdadeira (Sardinella brasiliensis). Sobre o óleo de sardinha brasileira, os publicados sobre a sua composição e produção são excassos (Badolato et al., 1991).

O óleo de pescado produzido é, normalmente, empregado para consumo animal e destinado para à produção de tintas, vernizes e acabamento de couros (BRASIL, 1985). Entretanto, não existem dados seguros sobre a produção total de óleo de pescado no Brasil.

Durante o "World Aquaculture 97" contatou-se que, nos anos seqüentes a 1997, haveria dependência, para a alimentação aqüícola, da produção de farinha e de óleo de peixe (Wiefels, 1998).

A maioria das espécies de peixe contendo pouca quantidade de óleo estão sendo excessivamente utilizadas para produção de ração animal. Para o aproveitamento das espécies com maior quantidade de óleo é necessário que se estabeleçam técnicas, inicialmente, que removam primeiro o óleo presente para aumentar a estabilidade do material e seu valor comercial (Potter et al.,1979).

Maia et al. (1998) caracterizaram a fração lipídica de silagens de resíduos de tilápia e concluíram que o óleo obtido do processo de silagem constitui-se numa fonte de lipídeos de alta qualidade e baixo custo. O óleo do pescado, em geral, é uma excelente fonte de energia, vitaminas A, D e ácidos graxos $\omega-3$.

Entretanto, o fornecimento de níveis elevados de óleo de pescado na dieta de animais monogástricos pode provocar a formação de "off-flavor" e prejudicar a aceitabilidade do produto (FAO, 2003). 
A fração lipídica, retirada para concentração da fração protéica, poderia ser utilizada como fonte lipídica, após adição de antioxidantes, na formulação de rações ou, ainda, ser utilizada como quimioatrativa ou palatabilizante de rações para peixes, porém, pesquisas devem ser conduzidas sobre esta utilização.

\subsection{Material e métodos}

\subsubsection{Matéria-prima}

A matéria-prima para obtenção da silagem química de pescado, constituiu-se de resíduo de tilápias do Nilo (Oreochromis niloticus) provenientes do cultivo comercial na região de Piracicaba, SP.

O material residual recuperado para elaboração da silagem era constituído de cabeça, nadadeiras, vísceras, coluna vertebral, pele e tecidos aderidos. O resíduo de tilápias utilizado foi proveniente da filetagem de 40 exemplares de tilápias (com peso total de $21 \mathrm{~kg}$ e peso médio dos exemplares de $500 \mathrm{~g}$ ), realizada nos laboratórios do Setor de Processamento de Alimentos do Departamento de Agroindústria, Alimentos e Nutrição da ESALQ/USP, conforme estabelecido por Oetterer (2002). O material residual recuperado para elaboração da silagem pesava $15 \mathrm{~kg}$ e era constituído de $7,7 \mathrm{~kg}$ de cabeças, 2,5 $\mathrm{kg}$ de nadadeiras, 1,5 $\mathrm{kg}$ de vísceras e 3,5 $\mathrm{kg}$ de coluna vertebral, pele e tecidos aderidos.

\subsubsection{Metodologia de elaboração da silagem}

A matéria-prima descrita no item 4.1 foi fragmentada em triturador, equipamento elétrico modelo ML-4.0/Weg- $\mu$ line, totalizando $15 \mathrm{~kg}$. Em seguida foi homogeneizada, pesada e distribuída, uniformemente, em 3 recipientes de plástico rígido. Adicionou-se o antioxidante BHT (hidroxibutilanisol), dissolvido em álcool etílico na concentração de $0,02 \mathrm{~g} / 100 \mathrm{~g}$ (BRASIL, 1998) e a mistura de ácidos (propiônico e fórmico na proporção 1:1), na relação de 3\% do volume da solução ácida para a massa de resíduo. As duas soluções foram adicionadas, manualmente, ao material homogeneizado, sob constante revolvimento, obtendo-se a silagem química de tilápia, na 
qual foi feito o controle diário do $\mathrm{pH}$ para que permanecesse próximo de 4,0 . As silagens permaneceram ao ambiente $\left(27^{\circ} \mathrm{C} \pm 1^{\circ} \mathrm{C}\right)$ por $72 \mathrm{~h}$, quando foram submetidas às análises de composição química. Na Figura 1 é apresentado o fluxograma de obtenção da silagem química de tilápia.

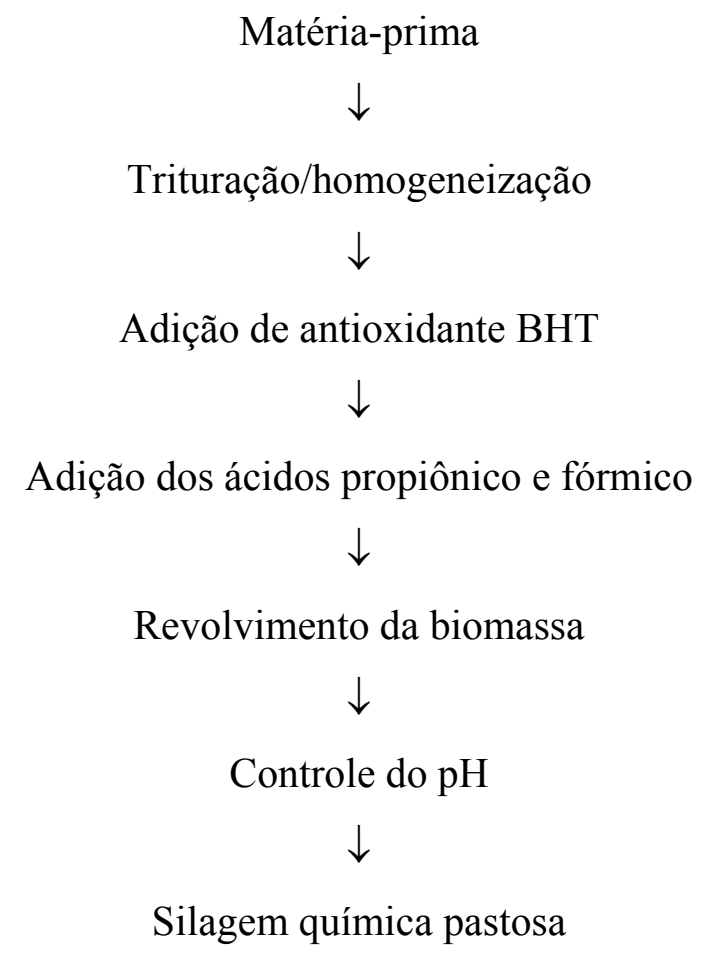

Figura 1- Fluxograma de obtenção da silagem química de tilápia.

\subsubsection{Obtenção do óleo de pescado}

A silagem elaborada foi centrifugada $(3000 \times \mathrm{G})$, durante $30 \mathrm{~min}$, após $24 \mathrm{~h}$ de hidrólise. Três fases foram obtidas, uma gordurosa, uma aquosa e outra emulsionada. A fração lipídica sobrenadante foi separada (óleo bruto A) com o auxílio de pipetas Pasteur, funis contendo papel de filtro qualitativo (Whatman n.4) e sulfato de sódio para retenção de resíduos sólidos e umidade remanescente. Para efeito de comparação de rendimento, entre os métodos de extração, procedeu-se à extração dos lipídeos pelo método de Soxhlet modificado, (óleo bruto B), com cartuchos forrados com algodão hidrófilo e sulfato de sódio anidro para controle da umidade excessiva, utilizando-se 
como solvente Hexano, conforme IUPAC (1979). O terceiro método ensaiado foi o de Bligh \& Dyer, (1959), (óleo bruto C), empregando-se o seguinte procedimento: utilizando as seguintes proporções: $100 \mathrm{~g}$ de amostra, contendo $80 \mathrm{~g}$ de água, foram homogeneizadas juntamente com $100 \mathrm{ml}$ de clorofórmio e $200 \mathrm{ml}$ de metanol. A solução foi novamente homogeneizada após adição de $100 \mathrm{ml}$ de clorofórmi e solução salina de $\mathrm{KCl}(0,88 \%$ p/v). Houve a formação de duas fases: uma inferior, contendo clorofórmio e a fração lípidica e a fase aquosa, contendo a fração não lipídica; esta foi retirada através de funis de separação.

\subsubsection{Análise de Rendimento em óleo}

As frações óleo bruto $\mathrm{A}$, óleo bruto $\mathrm{B}$ e óleo bruto $\mathrm{C}$ foram submetidas à evaporação, em evaporador rotativo a vácuo, e pesadas para cálculo do rendimento em óleo, em relação a silagem de origem. Os resultados foram expressos em porcentagem.

\subsubsection{Preparação das amostras de óleo para análise}

As amostras de óleo de pescado foram acondicionadas em frascos ambar, sob atmosfera de nitrogênio gasoso, e armazenadas em congelador à temperatura de $-18^{\circ} \mathrm{C}$, para utilização posterior.

\subsubsection{Análises físico-químicas}

Foram realizadas análises para determinação da composição centesimal da silagem química de tilápia e da fase emulsionada da silagem centrifugada, além do teor de proteína bruta na fase aquosa. Todas as análises foram realizadas em triplicata e de acordo com A.O.A.C, (1990).

A umidade foi determinada através do método gravimétrico, em estufa a $105^{\circ} \mathrm{C}$ até peso constante. $\mathrm{O}$ teor de cinza foi medido pelo método gravimétrico, em mufla a $550^{\circ} \mathrm{C}$ e incineração da matéria orgânica em bico de Bunsen. A análise de proteínas foi realizada através do método Micro-Kjeldhal, com digestão em bloco digestor e em seguida destilação e titulação com ácido sulfúrico $0,02 \mathrm{~N}$. A fração lípidica foi obtida 
pelo extrator Soxhlet, utilizando-se como solvente, o éter de petróleo, seguido de aquecimento em estufa até evaporação total do solvente.

\subsection{7. Índice de Peróxido}

Foram realizadas análises de índice de peróxido, em duplicata, nos óleos de pescado, preparados conforme descrito no item 4.3 e de acordo com A.O.C.S., (1990). A análise foi realizada através da diluição de amostras de $5 \mathrm{~g}$ de óleo em solução de ácido acético e clorofórmio (3:1) e adição de solução de iodeto de potássio saturada e água destilada. A seguir titulou-se com solução de tiossulfato de sódio e o volume gasto, após adição de solução de amido $0,1 \%$, forneceu a concentração em peróxidos em meq $\mathrm{O}_{2} / 1000 \mathrm{~g}$ de amostra.

\subsubsection{Composição e caracterização do óleo bruto obtido através da centrifugacão}

Foram realizadas análises de composição e caracterização, incluindo índices de peróxido e de acidez no óleo bruto extraído por centrifugação, em duplicata, de acordo com A.O.C.S (1990) e a composição de ácidos graxos presentes no óleo bruto através de cromatografia gasosa.

\subsubsection{1 Índice de acidez (IA)}

Foi realizado com a dissolução de amostras de $5 \mathrm{~g}$ de óleo em álcool etílico a quente $\left(65^{\circ} \mathrm{C}\right)$ e posterior titulação com solução de hidróxido de sódio padronizada. $\mathrm{O}$ ponto de viragem foi verificado com adição do indicador fenolftaleína.

\subsubsection{Preparo dos ésteres metílicos para cromatografia gasosa}

Os ésteres metílicos foram obtidos conforme metodologia descrita por Hartman \& Lago (1973).

No processo de transesterificação, o material lipídico extraído foi descongelado, homogeneizado e, aproximadamente, $200 \mathrm{mg}$ da amostra foram transferidos para tubo de ensaio com tampa rosqueável; adicionou-se $5 \mathrm{~mL}$ de $\mathrm{NaoH}$ metanólica, seguido de aquecimento por imersão em água a $65-70^{\circ} \mathrm{c}$ por $15 \mathrm{~min}$. À solução quente adicionou- 
se $10 \mathrm{ml}$ do reagente de esterificação (solução de cloreto de amônia e ácido sulfúrico em metanol). Em seguida retornou-se para o aquecimento por 10min. Após o resfriamento, ao ambiente, adicionou-se $2 \mathrm{ml}$ de éter de petróleo e completou-se o volume com solução saturada de cloreto de sódio.

\subsubsection{Composição de ácidos graxos presentes no óleo bruto}

A determinação da composição de ácidos graxos presentes no óleo bruto foi realizada através de cromatógrafo gasoso com detector de ionização de chama, marca comercial Konic, modelo HRGC $4000^{\mathrm{A}}$, em coluna cromatográfica de sílica fundida-CP Sil 88 Tailor Made FAME(Chrompak). A cromatografia gasosa foi realizada conforme AOCS (1998) - métodos Ce 1-62; Ce 1b-89; Ce 1c-89. A temperatura da coluna programada na faixa de $180{ }^{\circ} \mathrm{C}$ a $225^{\circ} \mathrm{C}$, com taxa de aquecimento de $1^{\circ} \mathrm{C}$ por minuto, enquanto que a temperatura do detector e do injetor foi fixada em $300^{\circ} \mathrm{C}$. A vazão do gás de arraste (Hidrogênio) foi de $0,5 \mathrm{~mL} / \mathrm{min}$.

O Padrão utilizado foi o ester metílico do ácido 1-decanóico. A identificação e quantificação dos ácidos graxos foi obtida por comparação do tempo de retenção utilizado e a área de pico dos ácidos graxos desconhecidos, com o padrão.

\subsection{Resultados e Discussão}

A elaboração de rações para a aqüicultura depende, atualmente, de grande aporte da farinha de peixe. Face à progressiva escassez desse insumo no mercado mundial, a silagem de pescado apresenta-se como uma fonte alternativa protéica, devido, principalmente, ao seu teor protéico (Tabela 1).

Conforme, Vidotti (2001), o tipo de processamento que originou o resíduo influencia, significativamente, o conteúdo lipídico da silagem e, conseqüentemente, a composição centesimal desta. Tatterson \& Windsor (1974) e Raa \& Gilberg, (1982) preconizam a retirada da fração lipídica para se obter um produto uniforme e com maior estabilidade.

A Tabela 1 apresenta os macro componentes da silagem química de tilápia. 
Tabela 1. Composição centesimal para a silagem de tilápia. (valores expressos em $\mathrm{g} / 100 \mathrm{~g}$ de matéria úmida e matéria seca)

\begin{tabular}{lcc}
\hline Componentes * & Matéria úmida $(\mathrm{g} / 100 \mathrm{~g})$ & Matéria seca $(\mathrm{g} / 100 \mathrm{~g})$ \\
\hline Matéria Seca & - & $21,68 \pm 0,83$ \\
Umidade & $78,32 \pm 0,81 * *$ & - \\
Matéria Mineral & $4,17 \pm 0,23$ & $19,23 \pm 0,24$ \\
Proteína Bruta & $12,85 \pm 0,65$ & $59,27 \pm 0,64$ \\
Extrato Etéreo & $3,99 \pm 0,35$ & $18,40 \pm 0,33$
\end{tabular}

*média de 3 repetições.

**desvio padrão da média.

O conteúdo de lipídios totais presente na silagem de tilápias, com base na matéria úmida é de 3,99 g/100g (Tabela 1), portanto, para evitar o problema de oxidação e provável perda conseqüente de aminoácidos, além de problemas sensoriais, foi retirada a fração lipídica, através de 3 métodos de extração: centrifugação (óleo bruto A), Soxhlet (óleo bruto B) e Bligh\& Dyer (óleo bruto C).

A Tabela 2 apresenta a composição centesimal da silagem após a centrifugação.

Tabela 2. Composição centesimal para a silagem de tilápia após centrifugação. (valores expressos em g/100g de matéria úmida e matéria seca)

\begin{tabular}{lcc}
\hline Componentes* $^{*}$ & Matéria úmida $(\mathrm{g} / 100 \mathrm{~g})$ & Matéria seca $(\mathrm{g} / 100 \mathrm{~g})$ \\
\hline Matéria Seca & - & $21,05 \pm .0,69$ \\
Umidade & $78,95 \pm 0,73 * *$ & - \\
Matéria Mineral & $2,49 \pm .0,41$ & $11,83 \pm 0,38$ \\
Proteína Bruta & $14,93 \pm 0,31$ & $70,93 \pm .0,27$ \\
Extrato Etéreo & $1,54 \pm .0,28$ & $7,32 \pm 0,34$ \\
\hline
\end{tabular}

* média de 3 repetições

** Desvio padrão da média 
A partir dos resultados de composição centesimal da silagem antes e após a centrifugação (Tabelas 1 e 2) pode-se aferir que restaram na amostra úmida 1,54 g/100g de lipídios, ou seja, o que é considerado aceitável, uma vez que é recomendável, de acordo com Nunes (1999), que a silagem participe com no máximo 20\% da proteína bruta e $1 \%$ de lipídios na elaboração da dieta. Com a retirada da fração lipídica, fator limitante, torna-se possível aumentar a inclusão da mesma na formulação de rações.

A Tabela 3 apresenta o rendimento e o índice de peróxido dos óleos obtidos com os métodos utilizados.

Tabela 3. Rendimento e índice de peróxido dos óleos obtidos via diferentes métodos de extração da fração lipídica. (valores expressos em \% de matéria úmida e $\mathrm{mEqO}_{2} / 1000 \mathrm{~g}$ de óleo)

\begin{tabular}{lcc}
\hline Métodos de extração & Rendimento (\%) & Índice de peróxido(mEq O $\left.\mathrm{m}_{2} / 1000 \mathrm{~g}\right)$ \\
\hline Centrifugação (óleo bruto A) & 65,53 & Zero \\
Soxhlet (óleo bruto B) & 44,27 & 25 \\
Bligh \& Dyer (óleo bruto C) & 46,87 & Zero \\
\hline
\end{tabular}

Souto et al. (2000) relataram que a determinação de lipídios em produtos de origem animal que possuem alto teor de umidade na sua constituição, com o emprego de Soxhlet (método tradicional) tem sido questionado. Como alternativas, os autores citaram o método de Bligh \& Dyer. Os autores atestaram que o método Bligh \& Dyer, ao utilizar dois tipos de solventes orgânicos possibilita a remoção de lipídios polares e não polares, sendo portanto, mais eficiente na extração de lipídios em produtos de pescado. Entretanto, comparando-se o rendimento e o índice de peróxido das frações lípidicas obtidas através dos métodos utilizados nesta pesquisa (Tabela 3), a centrifugação demonstrou ser a melhor metodologia de extração da fração lípidica presente na silagem, por permitir maior rendimento e preservar as características físicoquímicas do óleo.

A habilidade de um solvente para romper as ligações entre lipídios e outras moléculas, através da solubilização da fração lipídica originou o conceito de " Lipídios 
Extraíveis" (Manirakiza et al., 2000). A extração pela metodologia de Soxhlet, freqüentemente, apresenta rendimento menor do que a que emprega o método preconizado por Bligh \& Dyer e não apresenta os "Lipídios Totais" contidos no material, mas os " Lipídios Extraíveis" (Smedes, 1999). De acordo com De Boer, (1988), a fração não extraída pelo método de Soxhlet é referida como "Lipídios Ligados". Além destes fatores, a extração por Soxhlet é influenciada pela temperatura, tempo e número de ciclos de extração, composição e polaridade do solvente, e pelo tipo de material a ser extraído (Sunarya et al., 1996; Smedes, 1999; Manirakiza et al., 2000).

O menor rendimento encontrado com esta pesquisa pela metodologia de Soxhlet (Tabela 3), pode ser atribuído à limitação do método, em obter apenas os "Lipídios Extraíveis" e, possivelmente, pela composição da silagem elaborada nesta pesquisa. A extração por Soxlhet conforme Manirakiza et al. (2000), é mais conveniente para materiais sólidos.

Foi demonstrado na Tabela 3 e relatado por De Boer (1988) e Randall et al., (1991) que a utilização de diferentes métodos de extração resultam em diferentes resultados de teores de lipídios. Entretanto, o rendimento esperado para o método de Bligh \& Dyer deveria ser maior, pois mede os lipídios totais. Porém, de acordo, com esses autores, quando utilizado por diferentes laboratórios, o método de Bligh \& Dyer apresenta alta variabilidade nos resultados. Iverson et al. (2001) relatam que em amostras contendo mais do que $2 \%$ de teor lipídico, o método de Bligh \& Dyer apresenta valores significativamente, subestimados para o teor lipídico. Os autores explicam que quanto maior o teor lipídico da amostra, maior pode ser o erro por subestimação, podendo alcançar até 50\%.

A tabela 4 apresenta o rendimento da centrifugação para retirada do óleo bruto A. 
Tabela 4. Rendimento da extração por centrifugação, para retirada do óleo bruto A, em relação à silagem de origem. (valores expressos em porcentagem de matéria seca)

\begin{tabular}{lccc}
\hline \multicolumn{1}{c}{ Silagem } & Rendimento(g/100g) & Umidade $(\mathrm{g} / 100 \mathrm{~g})$ & Proteína $(\mathrm{g} / 100 \mathrm{~g})$ \\
\hline Fase Óleo Bruto 1 & $2,62 \pm 0,41$ & - & - \\
Fase Aquosa & $31,84 \pm 0,39$ & 90,08 & 8,32 \\
Fase Emulsionada & $65,53 \pm 0,47$ & - & - \\
\hline
\end{tabular}

Conforme anteriormente relatado por Windsor (1974), e Raa \& Gilberg, (1982) e na presente pesquisa, a silagem se liquefez e a centrifugação pôde isolar 3 fases: uma camada de lipídios, uma fase aquosa e uma fase emulsionada decantada (Tabela 4).

Morais et al. (2001) ao estudarem o processo de refino do óleo bruto de pescado, obtido através de aquecimento e prensagem da farinha de peixe, relataram que o óleo bruto utillizado como matéria-prima foi de baixa qualidade. A centrifugação, por ser um método mecânico, ao retirar a fração lipídica presente na silagem, à qual já havia sido adicionado antioxidante (BHT), não provocou aquecimento e, portanto, propiciou a retirada do óleo de pescado em boas condições fisico-químicas.

Podemos relacionar a facilidade de procedimento e a economicidade da centrifugação perante os outros métodos utilizados (Tabelas 3 e 4). A centrifugação não envolve solventes que encarecem e dificultam o processo por serem explosivos e tóxicos, como o método de Bligh \& Dyer, além de ser rápida e simples e não provocar aumento de temperatura como o método de Soxhlet, que pode provocar a perda de aminoácidos pela oxidação e formação de peróxidos. Portanto, em se tratando do destino dado a um resíduo, a centrifugação parece ser o método mais eficiente.

A Tabela 5 apresenta os ácidos graxos presentes na fração lipídica do óleo de tilápia obtido por centrifugação. 
Tabela 5. Composição de ácidos graxos do óleo bruto de tilápia obtido por centrifugação

\begin{tabular}{lc}
\hline Ácidos Graxos & Óleo Bruto A $(\mathrm{g} / 100 \mathrm{~g})$ \\
\hline Dodecanóico C12 & 0,11 \\
Mirístico C14 & 4,74 \\
Pentadecanóico C15 & 0,81 \\
Palmítico C16 & 33,19 \\
Palmitoléico C16:1 & 9,94 \\
Margárico C17 & 0,56 \\
Esteárico C18 & 5,60 \\
Oléico C18:1 & 28,60 \\
Linoléico C18:2 & 16,30 \\
Linolênico C18:3 & 3,10 \\
Octadecatetraenóico C18:4 & 1,50 \\
Aráquídico C20 & 1,30 \\
cis-11-Eicosenóico C20:1 & 1,60 \\
Eicosapentaenóico C20:5 & $<0,01$ \\
Docosahexaenóico C22:6 & $<0,01$ \\
\hline
\end{tabular}

Conforme apresentado na Tabela 5, os ácidos graxos presentes na fração lipídica da silagem são, predominantemente, os insaturados, sendo que o oléico apresentou-se em maior quantidade. Já entre os ácidos graxos saturados, o palmítico e o esteárico se apresentam em teores mais elevados. Estes resultados estão em conformidade com os apresentados por Maia et al. (1998), Sales (1995) e Valério (1994).

Nesta pesquisa foram encontrados apenas traços dos ácidos graxos EPA e DHA, diferindo dos resultados obtidos por Maia et al. (1998), que obtiveram valores de 2,3 e 9,7g de EPA e DHA/100g de óleo respectivamente, na silagem ácida de resíduo de tilápia. Espíndola Filho (1999) encontrou valores de 1,1g/100g de óleo para o EPA e $1,1 \mathrm{~g} / 100 \mathrm{~g}$ de óleo para o DHA, estudando a silagem ácida com 60 dias de armazenamento e produzida a partir de diferentes matéria-primas. 
Estudos realizados por Noffs et al. (2001) apresentaram a composição em ácidos graxos por cromatografia gás-líquido do efluente recolhido do enlatamento da sardinha brasileira e os teores para EPA e DHA foram respectivamente, 8,50 e 22,45\% do total de ácidos graxos. Entretanto, no caso da fração lipídica, extraída da silagem de pescado os teores para EPA e DHA apresentados na Tabela 5 demonstram que o óleo da silagem química de tilápias não pode ser considerado boa fonte de EPA e DHA.

Visentainer et al. (2000) estabeleceram a composição de ácidos graxos para resíduo de tilápias (cabeças), bem como quantificaram os ácidos graxos linolênico (LNA), EPA e DHA. A quantificação dos ácidos graxos LNA e DHA, em mg por grama de lipídios totais, foi de 4,94 e 3,93, respectivamente. O ácido graxo EPA não foi detectado. Esta variação entre os resultados encontrados na presente pesquisa e os quantificados por Visentainer et al. (2000), possivelmente são atribuídos às características diferentes dos resíduos utilizados. Tocher et al. (1997) demonstraram que silagens preparadas apenas de cabeças de peixes possuem maiores concentrações de ácidos graxos poliinsaturados.

O índice de acidez para o óleo bruto obtido por centrifugação foi de 19,81 ( $\mathrm{mgNaOH} / \mathrm{g})$. O elevado índice de acidez obtido para o óleo bruto era esperado devido a solução ácida utilizada no preparo e manutenção da silagem.

Os valores para os ácidos graxos, EPA e DHA (Tabela 5) foram inexpressivos neste experimento e, portanto, não justifica a utilização como suplemento alimentar humano ou para animais. Entretanto, outras pesquisas devem se realizadas para uma possível utilização do óleo como palatabilizante ou atrativo em rações.

\subsection{Conclusões}

A extração do óleo da silagem foi mais efetiva por meio da centrifugação, quando foi atingido o maior rendimento $(65,53 \%)$, maior estabilidade, além de rapidez e simplicidade do método.

A silagem submetida à extração por centrifugação apresentou teor remanescente de $1,54 \mathrm{~g} / 100 \mathrm{~g}$ de lipídios, suficiente para permitir a estabilidade da mesma. 
A extração por Soxlhlet levou à obtenção de óleo de elevado índice de peróxido (25 mEq/1000g de óleo) e baixo rendimento (44,27\%).

A metodologia de Bligh \& Dyer não apresentou índice de peróxido, porém, o rendimento foi baixo $(46,87 \%)$.

A fração lipídica da silagem de tilápia apresentou teores de EPA e DHA insuficientes para ser utililizada como fonte destes. 


\section{CONCLUSÕES GERAIS}

A bioconversão do material residual, com conseqüente aproveitamento deste, pode trazer vantagens econômicas para a indústria, além de sanar o grande problema de eliminação de resíduos, material poluente e de difícil descarte.

A partir do experimento realizado pode-se afirmar que o processo para a obtenção do ensilado é simples, prático e econômico, não requerendo equipamentos e procedimentos custosos. A silagem ácida de resíduo de tilápia apresentou-se pastosa e homogênea a partir de $24 \mathrm{~h}$ da elaboração, sob temperatura ambiente de $26-30^{\circ} \mathrm{C}$.

A silagem apresenta 59,27 g/100g de proteína bruta, na matéria seca, e todos os aminoácidos essenciais em teores semelhantes ou maiores aos preconizados pelo padrão FAO, à exceção do triptofano.

Os aminoácidos leucina e lisina apresentaram-se com os teores mais elevados, de 7 e $6,66 \mathrm{mg} / 100 \mathrm{~g}$ de proteína, respectivamente.

Os aminoácidos treonina, valina, metionina, isoleucina e lisina apresentaram-se com teores mais elevados que o padrão da FAO.

Os resultados indicam uma possível utilização da silagem preparada, a partir do resíduo de processamento da Tilápia do Nilo (Oreochromis niloticus), na formulação de ração para cultivo de peixes. Entretanto, novos estudos que avaliem desempenho e ganho de peso devem ser realizados para determinação da quantidade de silagem a ser incluída na formulação de rações e, também, pesquisas sobre a digestibilidade da fração proteíca.

Maiores estudos devem ser desenvolvidos para avaliação da quantidade ideal de inclusão da silagem na elaboração de rações para peixes. O aproveitamento dos resíduos 
será um importante fator econômico para as indústrias comercializadoras de produtos de pescado, assim como para diminuição dos custos de rações.

Estimando-se que cerca de $50 \%$ do custo de produção em aquicultura se deve ao manejo alimentar, com a redução dos custos das rações, deverá haver diminuição do preço de pescado ofertado e maior facilidade de aquisição pelo consumidor.

É possível discernir sobre a necessidade de padronização e manutenção da qualidade nutricional da silagem. A redução do teor de lipídios, bem como, a inclusão de antioxidantes no preparo da silagem permitirá a produção de uma silagem de pescado mais uniforme e adequada para a formulação de rações.

Atualmente, conforme a literatura consultada, o grau de hidrólise protéico é considerado como indicador da qualidade da silagem. Entretanto, é necessário que mais estudos sobre as reações de oxidação lipídica e possível indisponibilização de aminoácidos sejam feitos e, também, sejam utilizadas como parâmetro de qualidade, as condições da fração lipídica presente.

$\mathrm{Na}$ possibilidade da silagem de pescado ser uma alternativa para a farinha de peixe, na formulação de rações, é interessante investigar se a fração lipídica presente poderia ter alguma influência na palatabilidade do produto final e, a exemplo do que já acontece com a farinha de peixe, determinar um nível máximo de lipídios provenientes da silagem na ração animal.

A extração do óleo da silagem foi mais efetiva por meio da centrifugação, quando foi atingido o maior rendimento $(65,53 \%)$, maior estabilidade, além de rapidez e simplicidade do método.

A silagem submetida à extração por centrifugação apresentou teor remanescente de $1,54 \mathrm{~g} / 100 \mathrm{~g}$ de lipídios, suficiente para permitir a estabilidade da mesma.

A extração por Soxlhlet levou à obtenção de óleo de elevado índice de peróxido (25 mEq/1000g de óleo ) e baixo rendimento (44,27\%).

A metodologia de Bligh \& Dyer não apresentou índice de peróxido, porém, o rendimento foi baixo $(46,87 \%)$.

A fração lipídica da silagem de tilápia apresentou teores de EPA e DHA insuficientes para ser utililizada como fonte destes. 


\section{REFERÊNCIAS BIBLIOGRÁFICAS}

ACKMAN, R. G.; McLEOD, C. Total lipds and nutritionally important fatty acids of some Nova Scotia fish and shelfish products. Canadian Institute Food Science Technology, v.24, n.4, p.390-398, 1988.

AMERICAN OIL CHEMIST'S SOCIETY. Official methods and recommended pratices of the American Oil Chemist's Society. 4 ed. Champaign, 1990.1345p.

AMERICAN OIL CHEMIST'S SOCIETY. Official Methods And recommended practices of the American Oil Chemists Society, 5 ed., Champaign, 1998. 1430p. $2 \mathrm{v}$.

ASSOCIATION OF OFFICIAL ANALYTICAL CHEMISTS. Official methods of analysis. 14.ed. Washington, 1990. 1141p.

BADOLATO, E. S. G. ; CARVALHO, J. B.; TAVARES, M.; et al.. Determination of eicosapentaenoic (EPA) and docosahexaenoic (DHA) acids in Brazilian Sardine (Sardinella brasiliensis) oil and in encapsulated sardine oil supplements. In: INTERNATIONAL MEETING ON FATS \& OILS TECHNOLOGY. Proceedings, 1991 p. 189-192, 
BADOlATO, E. S. G.; CARVAlHO, J. B. de; AMARAL MELlO, M. R. P.; et al. Composição centesimal, de ácidos graxos e valor calórico de cinco espécies de peixes marinhos nas diferentes estações do ano. Revista do Instituto Adolfo Lutz, v.54, n. 1, p.27-35, 1994.

BACKHOFF, H.P. Some chemical changes in fish silage. Journal of Food Technology, v.11, n.4, p.353-363, 1976.

BELDA, M. C. R.; POURCHET-CAMPOS, M. A. Ácidos graxos essenciais em nutrição: uma visão atualizada. Ciência e Tecnologia de Alimentos, v.11, n.1, p.5$35,1991$.

BERENZ, Z. Utilización del ensilado de residuos de pescado en pollos. http://www.fao.org/waicent/faoinfo/agricult/aga/agap/aph134/cap2.htm. 1994. 11p. (25 fev. 2003)

BIMBO, A. P. The emerging marine oil industry. The Journal American of the Oil Chemists' Society, v.46, n.5, p.706-715, 1987.

BLIGH, E. G.; DYER, W. J. A rapid method of total lipid extraction and purification. Canadian Journal Biochemistry Physiology, v.37, p.911-917, 1959.

BOBBIO, P. A.; BOBBIO, F.O. Química do processamento de alimentos. 3.ed. Varela: São Paulo, 2001, p.145p.

BRONGEEST-SCHOUT, H. C.; VAN GENT, C. M.; LUTEN, J. B.; et al.. The effects of various intakes of n-3 fatty acids on the blood lipid composition in health human subjects. The American Journal of Clinical Nutrition, v.34, p.1752-1757, 1981. 
BROWN, N.; SUMMER, J. Fish silage. In: RELLY, A. Spoilage of tropical fish and products development. Roma: FAO, 1985. p.404-413.

BUDOWSKI, P. Nutritional effects of n3-polyunsaturated fatty acids. Israel Journal Medicine Science, v.17, p.223-231, 1981.

BRASIL. Ministério da Indústria e Comércio. Reciclagem dos resíduos urbanos, agropecuários e minerais. Brasília: Síntese, 1985.

BRASIL. Ministério da Agricultura e do Abastecimento. Compêndio Brasileiro de Alimentação Animal. Brasília: Departamento de Fiscalização e Fomento Animal, 1998.

BRASIL. Ministério da Agricultura e do Abastecimento. Setor pesqueiro.

http://www.setorpesqueiro.com.br/ministerios/ministerio_da_agricultura_e_do_abas tecimento/dpa/cadeias_produtivas/tilapia/prod_brasileira.shtm (26 fev. 2002).

CASTAGNOLLI, N. Piscicultura intensiva e sustentável de espécies nativas brasileiras. In: SIMPÓSIO SOBRE MANEJO E NUTRIÇÃO DE PEIXES, Piracicaba, 1997. Anais. Campinas: CBNA, 1997. p.117-130.

CASTAGNOLLI, N. Situação atual e perspectivas da aquicultura no Brasil. In: SIMPÓSIO SOBRE NUTRIÇÃO DE PEIXES E CRUSTÁCEOS, Campos do Jordão,1995. Anais. Campinas: CBNA, 1995. p. 1-8.

CHAMBERS IV, E.; ROBEL, A. Sensory characteristics of selected species of freshwater fish in retail distribution Journal of Food Science, v.58, n.3, p.508-561, 1993. 
CHENG, Z.J.; HARDY, R.W.; USRY, J.L. Effects of lysine supplementation in plant protein-based diets on the performance of rainbow trout (Oncorhynchus mykiss) and apparent digestibility coefficients of nutrients. Aquaculture, v.215, p.255-265, 2003.

CHONG, A. S. C.; HASHIM, R.; ALI, A. B. Assesment of dry matter and protein digestibilities of selected raw ingredients by discus fish (Symphysodon aequifasciata) using in vivo and in vitro methods. Aquaculture Nutrition, v. 8, p.229-238, 2002.

COELLO, N.; BRITO, L.; NONUS, M. Biosynthesis of L-lysine by Corynebacterium glutamicum grown on fish silage. Bioresource Technology, v.73, p.221-225, 2000.

CYRINO, J.E.P. Condicionamento alimentar e exigências nutricionais de espécies carnívoras: desenvolvimento de uma linha de pesquisa. Piracicaba, 2000. 200p. Tese (Livre-Docência) - Escola Superior de Agricultura "Luiz de Queiroz", Universidade de São Paulo.

DAPKEVICIUS, M.L.E.; BAPTISTA, I.; NOUT, M.J.R. et al. Lipid and protein changes during the ensilage of blue whiting (Micromesistius poutassou Risso) by acid and biological methods. Food Chemistry, v.63, n.1, p.97-102, 1998.

DAPKEVICIUS, M.L.E.; NOUT, R.M.J.; ROMBOUTS, F.M. et al. Biogenic amine formation and degradation by potencial fish silage starter microorganisms. International Journal of Food Microbiology, v.57, p.107-114, 2000.

DAS, H.K.; HATTULA, M. T.; MYLLYMÄKI, O.M.; et al. Effects of formulation and processing variables on dry fish feed pellets containing fish waste. Journal of the Science of Food and Agriculture, v.61, p.181-187, 1993. 
DE BOER, J. Chlorobiphenyls in bound and non-bounded lipids of fishes; comparison of different extraction methods. Chemosphere, v.17, p.1803-1810, 1988.

DISNEY, J. G.; HOFFMAN, A. Development of a fish silage/carbohydrate animal feed for use in the tropics. Tropical Science, v.20, n. 2, p.129-144, 1978.

DISNEY, J.G.; TATTERSON, I.N.; OLLEY, J. Recent developments in fish silage. In: CONFERENCE ON THE HANDLING, PROCESSING AND MARKETING OF TROPICAL FISH, London, 1976. Proceedings. London: Ministry of Oversea Development, 1977. p.321- 340.

EL-SAYED, A.F.M. Alternative dietary protein sources for farmed tilapia, Oreochromis spp. Aquaculture, v.179, p.149-168, 1999.

ESPE, M.; HAALAND, H.; NJAA, L. R. Autolysed fish silage a feed ingredient for Atlantic Salmon (Salmo salar). Composition Biochemistry Physiology, v.103, n.2, p.369-372, 1992.

ESPE, M.; LIED, E. Fish silage prepared from different cooked and uncooked raw materials: Chemical changes during storage at different temperatures. Journal of the Science Food and Agriculture, v.79, p.327-332, 1999.

ESPÍNDOLA FILHO, A. Aproveitamento de resíduos sólidos de pescado como fertilizante marinho. São Paulo, 1997. 98p. Dissertação (Mestrado) - Universidade Machenzie.

ESPÍNDOLA FILHO, A. Aproveitamento do resíduo sólido de peixe, camarão e bivalves como ingrediente de ração para aqüicultura. São Paulo, 1999. 224p. Tese (Doutorado) - Universidade Mackenzie. 
FAGBENRO, O. Dried fermented fish silage in diets for Oreochromis niloticus. The Israeli Journal of Aquaculture, v.46, n.3, p.140-147, 1994.

FAGBENRO, O.; BELLO-OLUSOJI, O.A. Preparation, nutrient composition and digestibility of fermented shrimp head silage. Food Chemistry, v.60, p.489-493, 1997.

FAGBENRO, O.; JAUNCEY, K. Water stability, nutrient leaching and nutritional properties of moist fermented fish silage diets. Aquacultural Engineering, v.14, p.143-153, 1995a.

FAGBENRO, O.; JAUNCEY, K. Growth and protein utilization by juvenile catfish (Clarias gariepinus) feed dry diets containing co-dried lactic-acid-fermented fishsilage and protein feedstuffs. Bioresource Technology, v.51, p.59-35, 1995 b.

FAGBENRO, O.; JAUNCEY, K.; HAYLOR, G. Nutritive value of diets containing dried lactic acid fermented fish silage and soybean meal for juvenile Oreochromis niloticus and Clarias gariepinus. Aquatic Living Resource, v.7, p.79-85, 1994.

FAGBENRO, O.; JAUNCEY, K. Physical and nutritional properties of moist fermented fish silage pellets as a protein supplement for tilapia (Oreochromis niloticus). Animal Feed Science Technology, v.71, p.11-18, 1998.

FAO. Energy and protein requeriments: Report of joint FAO/WHO/ONU Expert Consulation Technical Report. Geneve: FAO/WHO and the United Nations University, 1985. (FAO Series n. 724).

FAO. Estatísticas da pesca. Roma: FAO, v. 91, 2000, p.141.

FAO. Animal feed resources information system. http://www.fao.org. (23 Jan. 2003a). 
FAO. Feeding pigs in the tropics. FAO Animal Production and Health, n.132. http://www.fao.org (24 Jan. 2003b).

FAO. Examen mundial de la pesca y aquacultura: Fisheries Information Sistem. http://www.fao.org. (10/jun/2004)

FONTAÍNHAS-FERNANDES， A.; GOMES， E.; REIS-HENRIQUES， M.A.; COIMBRA, J. Replacement of fish meal by plant proteins in the diet of Nile tilapia: digestibility and growth performance. Aquaculture International, v.7, p.57-67, 1999.

FURUYA, W. M. Digestibilidade aparente de aminoácidos e substituição da proteína da farinha de peixe pela do farelo de soja com base em proteína ideal em rações para a tilápia do Nilo (Oreochromis niloticus). Botucatu, 2000. 69p. Tese (Doutorado) Faculdade de Medicina Veterinária e Zootecnia, Universidade Estadual Paulista "Júlio de Mesquita Filho".

FURUYA, W.M.; PEZZATO, L.E.; MIRANDA, E.C. et al. Coeficiente de digestibilidade aparente da energia e nutrientes de alguns ingredientes pela tilápia do Nilo (Oreochromis niloticus). In: REUNIÃO ANUAL DA SOCIEDADE BRASILEIRA DE ZOOTECNIA, 38, Piracicaba, 2001. Anais. Piracicaba: FEALQ, 2001. p.1407-1408.

GOODNIGHT, S. H.; HARRIS S.W.; CONNOR W. E.; ILLINGWORTH, R. D. The effect of dietary $\omega-3$ fatty acids on plaquet composition and function in man: a prospective controlled study. Blood, v.58, p.880-885, 1981.

GODDARD, J. S.; AL-YAHYAI, D. S. S. Chemical and nutritional characteristics of dried sardine silage. Journal of Aquatic Food Product Technology, v.10, n.4, p.39-50, 2001. 
GREENSHIELDS, R. N. The biotech concept of the food processing wastes. Outlook on Agriculture, v.21, n.2, p.94-104. 1992.

GILBERG, A. \& RAA, J. Properties of a propionic acid/formic acid preserved silage of food viscera. Journal of Science Food and Agriculture, n.28, n.647-53, 1977.

GUZMÁN, J.M.; VIANA, M. T. Growth of abalone Haliotis fulgens fed diets with and without fish meal, compared to a commercial diet. Aquaculture, v.165, p.321-331, 1998.

HAARD, N. F.; KARIEL, N.; HERZBERG, G.; et al. Stabilization of protein and oil fish in silage for use as a ruminant feed supplements. Journal of the Science of Food and Agriculture, v.36, n.4, p.229-241, 1985.

HAARD, N. F. Control of chemical composition and food quality attributes of cutured fish. Food Research International, v.25, p. 289-307, 1992.

HAMMOUMI, A.; FAID, M.; EL-YACHIOUI, M.; AMAROUCH, H. Characterization of fermented fish waste used in feeding trials with broilers. Process Biochemistry, v.33, n.4, p.423-427, 1998.

HASSAN, T.E; HEATH, J.L. Chemical and nutritive characteristics of fish silage produced by biological fermentation. Biological Wastes, v.20, n.3, p.187-201, 1987.

HARTMAN, L.; LAGO, R. C..A. Rapid preparation of fatty acid methyl esters from lipids. Laboratory Practice, v.22, p.475-477, 1973. 
HERAS, H.; MCLEOD, C.A.; ACKMAN, R.G. Atlantic dogfish silage vs. herring silage in diets for Atlantic salmon (Salmo salar): growth and sensory evaluation of fillets. Aquaculture, v.125, p.93-103, 1994.

HOOD, L. F. \& ZALL, R. R. Recovery, utilization and treatment of seafood processing wastes. Advanced Fishery Science and Tecnology, p.336-61, 1979.

HONCZARYK, A.; MAEDA, L.S. Crescimento do pirarucu, Arapaima gigas, utilizando dieta à base de ensilado biológico de pescado. In: SIMPÓSIO BRASILEIRO DE AQÜICULTURA, 10., Recife, 1998, Anais. Recife: Persona, 1998. v.2, p.93-100.

HORISBERGER, M. Lessons from the past for better future utilization of fish resources. In: Nestlé Products Technical Assistance, 1978/79. Lausanne: Nestlé Research News, 1979. p.41-49.

HUSSAIN, R.A.K.; OFFER, N. W. Effect of folmaldehyde treatment on the degradation of acid-preserved fish silage protein in vitro. Animal Feed Science and Technology, v.16, p.297-304, 1987.

INTERNATIONAL UNION OF PURE AND APPLIED CHEMISTRY. Standard methods for the analysis of oils, fats and derivatives. 6. ed. Oxford, 1979. 1360p.

IVERSON, S. J.; LANG, S. L. C.; COOPER, M. Compararison of the Bligh and Dyer and Folch Methods for total lipid determination in a broad range of marine tissue. Lipids, v.36, n.11, p.1283-1287, 2001.

JACKSON, A.J.; KERR, A.K.; COWEY, C.B. Fish silage as a dietary ingredient for salmon. I. Nutritional and storage characteristics. Aquaculture, v.38, p.211-220, 1984a. 
JACKSON, A.J.; KERR, A.K.; BULLOCK, A.M. Fish silage as a dietary ingredient for salmon. II. Preliminary growth findings and nutritional pathology. Aquaculture, v.40, p.283-291, $1984 b$.

JOHNSON, R.J.; BROWN, N.; EASON, P.; et al. The nutritional quality of two types of fish silage for broiler chickens. Journal of the Science of Food and Agriculture, v.36, p.1051-1056, 1985.

KOMPIANG, I. P. Fish silage: its prospect and future in Indonesia. Indonesia Agricultura Research \& Development Journal, v.3, n.1, p.9-12, 1981.

LAUBIER, L. Aquaculture: biological aspects and economic considerations. In: Nestlé Research News. 1978/79. Lausanne, Nestlé Products Technical Assistance, 1979.

LESSI, E; XIMENES CARNEIRO, A. R.; LUPIN, H. M. Obtención de ensilado biológico. In: CONSULTA DE EXPERTOS SOBRE TECNOLOGIA DE PRODUCTOS PESQUEROS EN AMERICA LATINA, 2, Montevideo, 1989.Anais. Roma: FAO, 1989. 8p.

LOVSHIN, L.L. Red tilapia or Nile tilapia: which is the best culture fish? In: SIMPÓSIO SOBRE MANEJO E NUTRIÇÃO DE PEIXES, 2., Piracicaba, 1998. Anais. Campinas: CBNA, 1998. p.179-198.

LOVSHIN, L.L.; CYRINO, P.E.P. Status of commercial fresh water fish culture in Brazil. In: SIMPÓSIO SOBRE MANEJO E NUTRIÇÃO DE PEIXES, 2., Piracicaba, 1998. Anais. Campinas: CBNA, 1998. p.1-20. 
LUPIN, H. M. Seminario sobre manipuleo, processamiento, mercade y distribución de los productos de la pesca continental en America Latina: ensilado Biológico de Pescado: una propuesta para la utili zación de resíduos. COMISSIÓN DE PESCA CONTINENTAL PARA AMÉRICA LATINA. México: Comissión de pesca continental para América Latina, 1989. 12p.

LUSTOSA NETO, A. D. Elaboração e caracterização química funcional e nutricional de ensilados de resíduos de pescado da família Lutjanidae. Fotaleza, 1994. 77p. Dissertação (Mestrado), Universidade Federal do Ceará.

MAIA, W. M. Adequação do processamento de silagens de resíduos de tilápia, caracterização dos lipídios e da fração seca em pó. João Pessoa, 1998. 116p. Dissertação (Mestrado em Tecnologia de Alimentos), Universidade Federal da Paraíba.

MAIA, W. M.; NUNES, M.L.; FIGUEIREDO, M.J.; BRAGAGNOLO, N. Caracterização da fração lipídica de silagem de resíduos de tilápia para utilização em rações para a aqüicultura. In: SIMPÓSIO BRASILEIRO DE AQUICULTURA, 10., Recife, 1998. Anais. Recife: Persona, 1998. v.2, p.55-64.

MAINARDES-PINTO, C. S. R.; VERANI, J. R.; ANTONIUTTI, D. M. Estudo comparativo do crescimento de machos de Oreochromis niloticus em diferentes períodos de cultivo. Boletim do Instituto de Pesca, v.22, p. 73-87, 1995.

MANIRAKIZA, P.; CORACI, A.; SCHEPENS, P. Comparative study on total lipid determination using Soxhlet, Roese-Gottlieb, Bligh \& Dyer, and Modified Bligh \& Dyer extraction methods. Journal of Food Composition and Analysis, v.14, p.93100, 2000. 
MANTRA, I. B. Growth and carcass production of pig fed fish silage as protein source. Majalah Ilmiah Peternakan, v.3, n.2, p.39-42, 2000.

MARTIN, A. M.; BEMISTER, P. L. Use of peat extract in the ensiling of fisheries wastes. Waste Management and Research, v.12, p. 467-479, 1994.

MENCIA MORALES, F.; NUNES, M. P. C.; AMADO, A. L.; SOUZA, R. R.; LEITE, L. V. N.; MACHADO, J. C. Avaliação da indústria pesqueira brasileira: capacidade, produção, mercado. Brasília: Ministério da Agricultura; SUDEPE; PNUD; FAO, 1976. 137 p.

MINAZZI-RODRIGUES, R. S.; PENTEADO, M. V. C. Importância dos óleos de peixe em fisiologia e nutrição humana. Caderno de Nutrição, n.3, p.41-97, 1991.

MOntenegro, A. A costa do Brasil. Folha de São Paulo, São Paulo, 17 maio 1998. p. 10. Oceanos.

MORAIS, C; MARTINS, J. F. P. Considerações sobre o aproveitamento de sobras da industrialização de pescado na elaboração de produtos alimentícios. Boletim do Instituto de Tecnologia de Alimentos, Campinas, v.3, p.253-281, 1981.

MOORE, I; STEIN, W.H. Chromatographic determination of amino acids by use of automatic recording equipaments. Methods in Enzymology, v.6, p.919-931, 1963.

MORAIS, M. M.; PINTO, L. A. A.; ORTIZ, S. C. A; et al.; Estudo do processo de refino do óleo de pescado. Revista do Instituto Adolfo Lutz, v. 60, n.1, p.23-33, 2001. 
MORALES-ULLOA, D. F. Bioconversão de resíduos da indústria pesqueira. Piracicaba, 1994. 127p. Dissertação (Mestrado) - Escola Superior de Agricultura "Luiz de Queiroz", Universidade de São Paulo.

MORALES-ULlOA, D. F.; OETTERER, M. Bioconversão de resíduos da indústria pesqueira. Ciência e Tecnologia de Alimentos, v.15, n.3, p.206-214, 1995.

MORALES-ULlOA, D.F.; OETTERER, M. Composição em aminoácidos de silagens químicas, biológicas e enzimáticas preparadas com resíduos de sardinha. Ciência e Tecnologia de Alimentos, v.17, n.3, p.252-258, 1997.

NEETHISELVAN, N.; JASMINE, G. I.; MANIKANDAVELU, D.; et al. Use of fermented fish ensilage in the diets of Etroplus suratensis (Bloch). Fishery Technology, v.38, n.1, p.43-47, 2001.

NOFFS, M.; CAMPOS, P.R. B.; SALLOWICS, F. A.; et. al. Fontes marinhas para obtenção de óleos com alto teor de ácidos graxos poliinsaturados ômega 3. In: SIMPÓSIO LATINO AMERICANO DE CIÊNCIA DE ALIMENTOS,.4. Campinas, 2001. Resumos. Campinas: SBAN, 2001. p.241.

NELSON, D.L.; COX, M.M. Lehninger principles of biochemistry. New York: Worth Publication, 2000. 145p.

NEW, M.; CSAVAS, I. Will there be enough fish meal for fish meals? Aquaculture Europe, v.19, n.3, p.6-13, 1995.

NOGUEIRA JUNIOR, S.; NEGRI NETO, A ; TSUNECHIRO, A ; OKANO, C.; SATO, G. S.; GIULIETTI, N.; TAKAHASHI, N. S.; TANAKA, R. T.; DIEHL, S. R. L. Alimentação animal: realidade e perspectivas (Coleção cadeias de produção da aqüicultura) São Paulo: Secretaria da Agricultura e Abastecimento, 1997, 95p. 
NUNES, M.L. Silagem de pescado. In: OGAWA, M.; MAIA, E.L. Manual de pesca. São Paulo: Livraria Varela, 1999. p.371-379.

OETTERER, M. Agroindústrias beneficiadoras de pescado cultivado: unidades modulares e polivalentes para implantação, com enfoque nos pontos críticos higiênicos e nutricionais. Piracicaba, 1999. 196p. Tese (Livre-Docência) - Escola Superior de Agricultura "Luiz de Queiroz", Universidade de São Paulo.

OETTERER, M. Industrialização do pescado cultivado. Guaíba: Agropecuária, 2002. 200 p.

OSTRENSKY, A.; BORGHETTI, J. R.; PEDINI, M. Situação atual da aquicultura brasileira e mundial. In: VALENTI, W. C. Aquicultura no Brasil: bases para um desenvolvimento sustentável. Brasilia: CNPQ/MCT, 2000. p.353-381.

OTTATI, M.; GUTIERREZ, M.; BELLO, R. Estudio sobre la elaboración de ensilado microbiano a partir de pescado proveniente de especies subutilizadas. Archivos Latinoamericanos de Nutrición, v.4, n.3, p.408-425, 1990.

PACCHIONI, V. M. Ácidos graxos essenciais ômega 3 e ômega 6 e sua utlilização em alimentos funcionais. Food Ingredients, n. 1, p. 24-25, 1999.

PARÍN, M.A.; ZUGARRAMURDI, A. Aspectos económicos del procesamiento y uso de ensilado de pescado. http:/www.fao.org/waicent/faoinfo/agricult/aga/cap4.htm. 1994. 16p. (25 fev. 2003) 
PEZZATO, L. E. Alimentos convencionais e não convencionais disponíveis para a indústria da nutrição de peixes e crustáceos. In: SIMPÓSIO INTERNACIONAL SOBRE NUTRIÇÃO DE PEIXES E CRUSTÁCEOS, 1., Campos do Jordão, 1995. Anais. Campinas: CBNA, 1995. p.34-52.

PORTZ, L. Recentes avanços na determinação das exigências e digestibilidade da proteína e aminoácidos em peixes. In: REUNIÃO ANUAL DA SOCIEDADE BRASILEIRA DE ZOOTECNIA, 38., Piracicaba, 2001. A produção animal na visão dos brasileiros. Piracicaba: FEALQ, 2001a. p.528-542.

PORTZ, L. Utilização de diferentes fontes protéicas em dietas formuladas pelo conceito de proteína ideal para o "black bass” (Micropterus salmoides). Piracicaba, 2001b. 111p. Tese (Doutorado) - Escola Superior de Agricultura "Luiz de Queiroz", Universidade de São Paulo.

POTTER, D.; TATTERSON, I.; WIGNALL, J. Preliminary studies of two technique for the removal of oil from fish silage using commercial equipment. In: CONNELL, J. J. Advances in fish science and technology. Surrey: FAO Fishing News Books, 1979. p.338-343.

RAA, J.; GILDBERG, A. Fish silage: a review. Journal of the Food Science and Nutrition, v.61, p.383-419, 1982.

RAA, M. E. J. \& NJAA, L. R. Nutritional value of stored fish silage as a protein source for young rats. Journal of Science Food and Agriculture, v.49, p.259-270, 1989.

RANDALL, R. C.; LEE, H.; OZRETICH, R. J.; et al. Evaluation of selected lipid methods for normalizing pollutant bioaccumulation. Environomental Toxicology Chemistry, v.10, p.1431-1436, 1991. 
REBECA, B. D.; PENA - VERA, M. T.; DIAS - CASTANEDA, M. Production of fish protein hydrolisates with bacterial proteases; yield and nutrional value. Journal of Food Sciense, v.56, n.2, p.309 -314, 1991.

RISTIC, M.D.; FILIPOVIC, S.S.; SAKAC, M.L.J. Liquid protein feedstuffs from freshwater fish by-products as a component of animal feed. Romanian Biotechnological Letters, v.7, n.3, p.729-736, 2002.

RIVERO, L.E.; VIANA, M. T. Effect of pH, water stability and toughness of artificial diets on the palatability for juvenile abalone, Haliotis fulgens. Aquaculture, v.144, p.353-362, 1996.

SALES, J.; BRITZ, P.J. Apparent and true availability of amino acids from common feed ingredients for South African abalone (Haliotis midae L.). Aquaculture Nutrition, v.9, p.55-64, 2003.

SALES, R. O. Processamento, caracterização química e avaliação nutricional da silagem da despesca da tilápia do Nilo (Oreochromis niloticus) em dietas experimentais com ratos. Campinas, 1995. 174p. Tese (Doutorado) - Faculdade de Engenharia de Alimentos, Universidade Estadual de Campinas.

SAMUELS, W.A.; FONTENOT, J.P.; ALLEN, V.G.; et al. Seafood processing wastes ensiled with straw: utilization and intake by sheep. Journal of Animal Science, v.69, p.4983-4992, 1991.

SGARBIERI, V.C. Alimentação e nutrição: fator de saúde e desenvolvimento. Campinas: UNICAMP, 1987. 387p. 
SHOEMAKER, S. The use of enzymes for waste management in food industry. In: HARLANDER, S.K.; LABUZA, T.P. Biotechnology in Food Processing. New Jersey: Noyes Publishing,1986. p.259-269.

SMEDES, F. Determination of total lipid using non-chlorinated solvents. Analyst, v.124, p.1711-1718, 1999.

SOUTO, S. K. C.; FREIRE, I. G. M.; MELO-FILHO, S. C., GUERRA, N. B. Determinação de lipídios em peixe curimã (Mugel lisa ): comparação entre os métodos de Soxhlet e de Bligh \& Dyer. In: CONGRESSO BRASILEIRO DE CIÊNCIA E TECNOLOGIA DE ALIMENTOS, 17, Fortaleza, 2000. Resumos. Fortaleza: SBCTA, 2000, v.1, p.291.

SPIES, J. R. Determination of tryptophan in proteins. Analytical Chemistry, v.39, p.1412-1415, 1967.

STANSBY, M. E. Nutritional properties of fish oils. World Review of Nutrition and Dietetics, v.11, p.46-105, 1969.

STONE, D. A. J.; ALLAN, G. L.; PARKINSON, S.; ROWLAND, S. J. Replacement of fish meal in diets for Australian silver perch, Bidyanus bidyanus, III-Digestibility and growth using meat meal products. Aquaculture, v.186, p.311-326, 2000.

STONE, F.E.; HARDY, R.W. Nutritional value of acid stabilised silage and liquefied fish protein. Journal of the Science of Food and Agriculture, v.37, p.797-803, 1986.

STROM, T.; EGGUM, R.W. Nutritional value of fish viscera silage. Journal of the Science of Food and Agriculture, v.32, p.115-120, 1981. 
SUNARYA; HOLE, M. ; TAYLOR , A. K. D. Methods of extraction composition and stability of vitamin A and other components in dog fish (Squalus acanthias) liver oil. Food Chemistry, v.55, n.3, p.215-220, 1996

TACHIBANA, L. Desempenho inicial e digestibilidade aparente de nutrientes de diferentes linhagens de tilápia do Nilo (Oreochromis niloticus). Jaboticabal, 2002. 46p. Dissertação (Mestrado) - Centro de Aqüicultura, Universidade Estadual Paulista "Júlio de Mesquita Filho".

TACON, A.G.J. Feed ingredients for carnivorous fish species: alternatives to fish meal and other fisheries resources. Roma: FAO, 1994. (FAO Fisheries Circular, $881)$.

TATTERSON, J. N.; WINDSOR, M. L. Fish silage. Journal of Science Food and Agriculture, n.25, p.369-379, 1974 .

TOCHER, D. R.; MOURENTE, G.; SARGENT, J. R. The use of silages prepared from fish neural tissues as enrichers for rotifers (Brachionus plicatilis) and Artemia in the nutrition of larval marine fish. Aquaculture, v.148, p.213-231, 1997.

TURATTI, J. M. Óleos vegetais como fonte de alimentos funcionais. Food Ingredients, n.9, p. 56-57, 2000.

UNITED NATION INDUSTRIAL DEVELOPMENT ORGANIZATION- UNIDO. Environmental management in fishery- based industries. (Working papers in industrial planning, 5), 1991, 88p.

VALENTI, W.C. Aquaculture for sustainable development. In: VALENTI, W.C.; POLI, C.R.; PEREIRA, J.A.; BORGHETTI, J.R. Aqüicultura no Brasil. Brasília: CNPq/Mistério da Ciência e Tecnologia, 2000. p.17-24. 
VALÉRIO, A. C. R. Elaboração de silagem enzimática de pescado como alternativa ao processo tradicional. Piracicaba, 1994, 102p. Dissertação (Mestrado)-Escola Superior de Agricultura "Luiz de Queiroz", Universidade de São Paulo.

VIANA, M. T.; CERVANTES-TRUJANO, M.; SOLANA-SANSORES, R. Attraction and palatability activies in juvenile abalone (Haliotis fulgens): nine ingredients used in artificial diets. Aquaculture, v.127, p.19-28, 1994.

VIANA, M. T.; GUZMAN, J.M.; ESCOBAR, R. Effect of heated and unheated fish silage as a protein source in diets for abalone Haliotis fulgens. Journal of the World Aquaculture Society, v.30, n.4, p.481-489, 1999.

VIANA, M. T.; LOPEZ, L. M.; GARCIA-ESQUIVEL, Z.; et al. The use of silage made from fish and abalone viscera as an ingredient in abalone feed. Aquaculture, v.140, p.87-98, 1996.

VIDOTTI, R.M. Produção e utilização de silagens de peixe na nutrição do pacu (Piaractus mesopotamicus). Jaboticabal, 2001. 65p. Tese (Doutorado) - Centro de Aqüicultura, Universidade Estadual Paulista "Júlio de Mesquita Filho".

VIDOTTI, R.M.; VIEGAS, E.M.M.; CARNEIRO, D..J. Amino acid composition of processed fish silage using diferent raw materials. Animal Feed Science and Technology, v.105, p.199-204, 2003.

VIZCARRA-MAGAÑA, L.A.; AVILA, E.; SOTELO, A. Silage preparation from tuna fish wastes and its nutritional evaluation in broilers. Journal of the Science of Food and Agriculture, v.79, p.1915-1922, 1999. 
VISENTAINER, J. V.; HAYASHI, C.; SOARES, C. M.; GALDIOLI, E. M.; FRANCO, M. R.; Quantificação de ácidos graxos ômega-3 (LNA, EPA e DHA), caracterização físico-química e composição de ácidos graxos em cabeças de tilápias jovens. In: CONGRESSO BRASILEIRO DE CIENCIA E TECNOLOGIA DE ALIMENTOS, 17, Fortaleza, 2000, Resumos. Fortaleza: SBCTA, 20000, v.2, p.223.

WIEFELS, R. C. Panorama da aqüicultura mundial. Infopesca Internacional. p.19-27, set/out, 1998.

WINDSOR, M. L. Production of liquid fish silage for animal feed. In: KREUZER,R. Fishery products. Surrey: FAO/ Fishing News Books. 1974, p.140-144.

XIMENES CARNEIRO, A.R. Elaboração e uso de ensilado biológico de pescado na alimentação de alevinos de tambaqui (Colossoma macropomum). Manaus, 1991. 81p. Tese (Mestrado) - Instituto Nacional de Pesquisas da Amazônia, Universidade Federal do Amazonas.

XIMENES CARNEIRO, A. R.; LESSI, E.; STIVAN, E. Ensilado biológico de pesces usado como fuente de proteínas en raciones para alevinos de tambaqui (Colossoma macropomum). In: CONSULTA DE EXPERTOS SOBRE TECNOLOGIA DE PRODUCTOS PESQUEROS EN AMERICA LATINA, 3., Porlomar, 1994. Trabajos. Roma: FAO, 1996. Cap.4, p. 98-103. (FAO Informe de Pesca, 548)

ZAHAR, M.; BENKERROUM, N.; GUEROUALI, A. et al. Effect of temperature, anaerobiosis, stirring and salt addition on natural fermentation silage of sardine and sardine wastes in sugarcane molasses. Bioresource Technology, v.82, p.171-176, 2002. 